
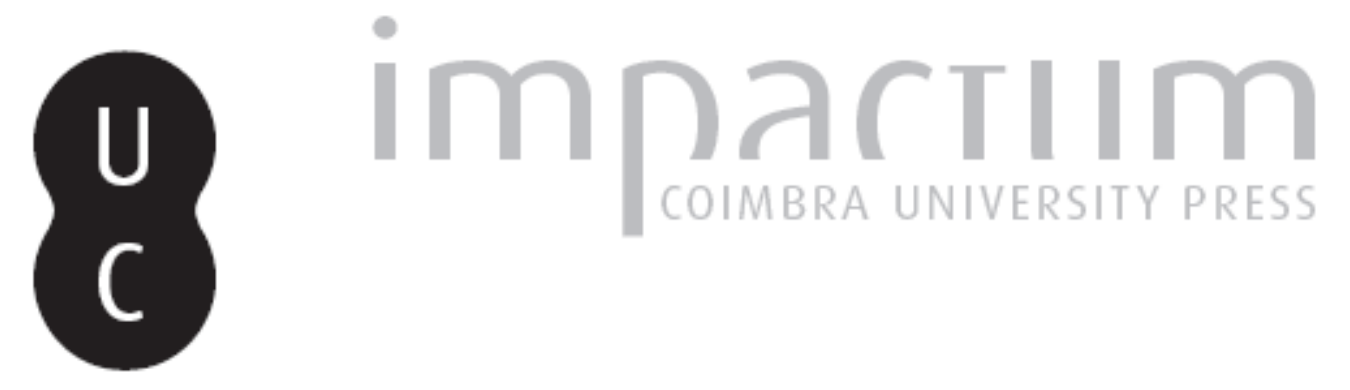

A assistência aos combatentes na I Guerra Mundial: um conflito ideológico

Autor(es): $\quad$ Moura, Maria Lúcia de Brito

Publicado por: Imprensa da Universidade de Coimbra

URL persistente:

URI:http://hdl.handle.net/10316.2/44998

DOI:

DOI:https://doi.org/10.14195/0870-4147_38_3

Accessed : $\quad$ 26-Apr-2023 05:25:29

A navegação consulta e descarregamento dos títulos inseridos nas Bibliotecas Digitais UC Digitalis, UC Pombalina e UC Impactum, pressupõem a aceitação plena e sem reservas dos Termos e Condições de Uso destas Bibliotecas Digitais, disponíveis em https://digitalis.uc.pt/pt-pt/termos.

Conforme exposto nos referidos Termos e Condições de Uso, o descarregamento de títulos de acesso restrito requer uma licença válida de autorização devendo o utilizador aceder ao(s) documento(s) a partir de um endereço de IP da instituição detentora da supramencionada licença.

Ao utilizador é apenas permitido o descarregamento para uso pessoal, pelo que o emprego do(s) título(s) descarregado(s) para outro fim, designadamente comercial, carece de autorização do respetivo autor ou editor da obra.

Na medida em que todas as obras da UC Digitalis se encontram protegidas pelo Código do Direito de Autor e Direitos Conexos e demais legislação aplicável, toda a cópia, parcial ou total, deste documento, nos casos em que é legalmente admitida, deverá conter ou fazer-se acompanhar por este aviso. 

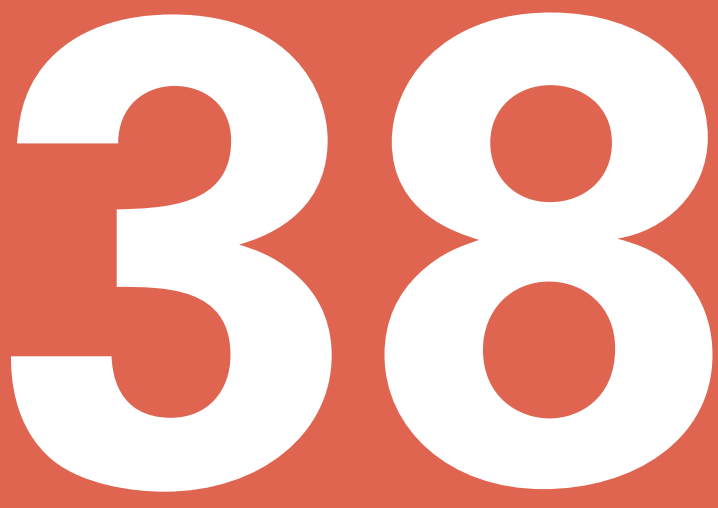

\section{Revista Portuguesa de História}

Faculdade de Letras da Universidade de Coimbra Instituto de História Económica e Social

Coimbra 08 
Revista Portuguesa de História

t. XXXVIII (2006)

pp. $41-75$

\title{
A Assistência aos combatentes na I Guerra Mundial - um conflito ideológico
}

Maria Lúcia de Brito Moura

CEHR - Centro de Estudos de História Religiosa

\begin{abstract}
A intervenção de Portugal na guerra, tão desejada pelo radicalismo republicano apoiante de Afonso Costa, introduziu novos contornos no conflito entre o Estado e a Igreja aberto após a queda da Monarquia. O sector intervencionista, ansioso por conquistar o apreço internacional para o regime e para o Governo e, ainda, acabar com as clivagens internas entre republicanos ${ }^{1}$, estabelecia uma relação de continuidade entre a desejada guerra contra a Alemanha e o movimento revolucionário de 5 de Outubro de $1910^{2}$. Não aceitava, por isso, estar do mesmo lado dos representantes da Igreja Católica ou dos monárquicos, preferindo isolar os opositores - a Igreja Católica continuava a
\end{abstract}

1 Veja-se Nuno Severiano Teixeira, O Poder e a Guerra 1914-1918. Objectivos Nacionais e Estratégias Públicas na Entrada de Portugal na Grande Guerra, Lisboa, Editorial Estampa, 1996, pp. 373-382.

2 Num texto publicado pela Universidade Livre, Bernardino Machado defendeu que a luta contra a Alemanha era a "continuação lógica da revolução que tinha produzido a República". Filipe Ribeiro de Meneses, União Sagrada e Sidonismo. Portugal em Guerra (1916-1918), Lisboa, Edições Cosmos, 2000, p. 86. 
ser o principal adversário ${ }^{3}$ - remetendo-os para o campo germanófilo. Contudo, muitos católicos (monárquicos ou não) estiveram desde o início ao lado da católica Bélgica, invadida pelos alemães que, segundo informavam os jornais, profanavam igrejas e assassinavam gente inocente. $\mathrm{O}$ apoio aos aliados não significa necessariamente que se desejasse um envolvimento directo na guerra, pelo menos nos combates que se travavam na Europa. Quanto à guerra em África, parecia existir consenso relativamente à necessidade de defender os territórios do império ultramarino.

Fosse qual fosse a posição sobre a interferência directa no conflito europeu, uma vez que a situação tomou um carácter irreversível a partir de 9 de Março de 1916 (data da declaração de guerra por parte da Alemanha), colocou-se a grande questão que preocupava os católicos: a assistência religiosa aos combatentes numa guerra que, considerando as notícias que chegavam dos exércitos já envolvidos, produziria entre os portugueses um elevado número de baixas. Quem assistiria aos soldados no momento da morte? Morreriam sem a absolvição dos pecados, que garantiria a salvação? Iriam para a sepultura sem um sacerdote que encomendasse a Deus as suas almas? Eram interrogações que atormentavam os crentes mas que não impressionavam os que, afastados há muito desses rituais liminarmente encarados como produtos da superstição, desejavam acabar com o poder que a Igreja Católica mantinha sobre as consciências da maioria dos portugueses.

Manifestações a favor ou contra a integração de capelães nas forças expedicionárias ${ }^{4}$ terão lugar no período entre a declaração de guerra e a publicação do decreto de 18 de Janeiro de 1917 que, a poucos dias da partida do primeiro contingente para a França, regulamentou a possibilidade de assistência religiosa em campanha.

É tendo em atenção estes diferendos que deveremos acompanhar as notícias veiculadas pela imprensa, a partir de 20 de Março de 1916, sobre os primeiros passos de uma associação feminina onde avultavam nomes da aristocracia monárquica: condessas de Burnay, de Ficalho, viscondessa de Santo Tirso, marquesa de Lavradio, Maria Leonor Van Zeller, Sofia Burnay de Melo Breyner ${ }^{5}$... A nova corporação, que tomou o nome de Assistência das

3 Maria Lúcia de Brito Moura, A Guerra Religiosa na Primeira República, Editorial Notícias, 2004, p. 392.

4 Arnaldo Madureira, A Questão Religiosa na I República. Contribuições para uma autópsia, Livros Horizonte, 2004, pp. 131-132.

5 Ainda não era designada "condessa", pois só depois da morte do cunhado, em 1922, é que o marido, o Dr. Tomás de Melo Breyner, se tornou o $4^{\circ}$ conde de Mafra. 
Portuguesas às Vitimas da Guerra ${ }^{6}$, sustentava não ter qualquer cor política. Propunha-se tão-só preparar formas de auxílio a prestar aos combatentes e suas famílias. Não se tratava de mais uma agremiação do mundo tradicional católico, que reservava às mulheres a prática da caridade cristã dirigida aos desprotegidos. Ambicionava ser mais que isso. Embora pretendesse apoiar as famílias dos soldados mais carenciados, o centro das suas preocupações parecia encontrar-se na assistência hospitalar ${ }^{7}$. Seguiam a via aberta por muitas mulheres da sua classe que, nos países em guerra - uma guerra que ia já no segundo ano - se ofereciam, em regime de voluntariado, para prestar serviço como enfermeiras.

Num tempo em que não existiam em Portugal estruturas que formassem enfermeiras de guerra, abriram imediatamente inscrições para cursos destinados ao sexo feminino. Circulava a convicção de que muitos dos feridos nos combates seriam repatriados, recebendo os tratamentos em Portugal. Assim, da parte de famílias abastadas surgiram ofertas de instalações que podiam facilmente ser adaptadas a enfermarias. A generosidade chegava ao ponto de se disponibilizarem a custear as despesas com o tratamento de um determinado número de feridos ${ }^{8}$.

Apesar de se tratar de uma associação feminina, com um projecto de trabalho envolvendo somente mulheres, alguns homens assistiram às primeiras reuniões, o que leva a supor que, na retaguarda de toda esta actividade, existisse um consenso entre uns e outros sobre a oportunidade da iniciativa. Aliás, um dos grandes dinamizadores da Assistência às Vítimas da Guerra era o Dr. Tomás Breyner, médico prestigiado de Lisboa, conhecido também pela sua militância católica e ligações à família real. A sogra, a condessa de Burnay, foi a primeira presidente do novo agrupamento ${ }^{9}$. É muito provável que a ideia da agremiação tenha a ver com a relutância do Governo em corresponder às reclamações do sector católico no sentido de ser assegurada a presença de capelães junto dos combatentes. Tomás Breyner viria a integrar a Comissão Central da Assistência Religiosa em Campanha ${ }^{10}$, criada pelo cardeal patriarca D. António Mendes Belo,

6 Sobre esta associação e o que ela se propunha, bem como sobre a sociedade rival - Cruzada das Mulheres Portuguesas -, Maria Teresa Viegas Pimenta apresentou uma comunicação em 1989. Maria Teresa Viegas Pimenta, “As Mulheres Portuguesas na Guerra de 1914/18”, As Mulheres, a Identidade Cultural e a Defesa Nacional, Actas do seminário realizado em 5, 6 e 7 de Abril de 1989, Cadernos da Condição Feminina, no 29, Ed. da Comissão da Condição Feminina, 1989, pp. 81-86.

7 Diário de Notícias, 20/03/1916, p. 1, col. 7 e 24/03/1916, p. 1, col. 8.

8 O Dia, 23/03/1916, p. 3, col. 2.

9 Ibidem.

${ }^{10}$ A lista de nomes dos que integravam a comissão pode ser vista em Avelino de Figueiredo, A Cruz na Guerra (uma missão difícil). Roteiro e impressões, Lisboa, Ed. do autor, 1960, p. 24. 
com o objectivo de reunir meios capazes de possibilitar a acção dos capelães, aos quais não fora atribuído pelo Estado qualquer subsídio. Melo Breyner não foi o único médico a interessar-se pelo projecto, sobretudo no respeitante à formação de enfermeiras. O seu intento ia mesmo de encontro ao propósito de outros médicos que sentiam a mesma premência. Aliás, o Dr. Reinaldo dos Santos, que dirigiria as aulas práticas - a Dra. Domitília Carvalho orientaria o curso de higiene -, esteve presente pelo menos em uma das primeiras reuniões preparatórias ${ }^{11}$.

A outro nível, teremos de ter presente o quadro estabelecido dos deveres das senhoras católicas educadas na responsabilidade para com o próximo desvalido. Quando um jornalista entrevistou a condessa de Ficalho, vice-presidente da comissão central do agrupamento e futura presidente, manifestou-lhe a simpatia por uma acção que, em seu entender, demonstrava grande "patriotismo e humanidade". Mas a condessa preferiu o termo "caridade", explicando que era "a palavra que define melhor o acto de fazer bem aos nossos semelhantes, por amor de Deus" 12 .

A nova associação ia deparar com muitos obstáculos. As forças apoiantes do Governo não se entusiasmaram com a movimentação de um sector que poderia aproveitar as circunstâncias para fazer campanha contra a política governamental, nomeadamente no campo religioso, procurando reconquistar posições perdidas com o advento do regime republicano ${ }^{13}$. O funcionamento dos cursos de enfermagem, que obrigava a aulas práticas em hospitais, seria em breve proibido pelo ministro do Interior. Ou melhor: as candidatas poderiam frequentar as aulas se estivessem inscritas na Cruz Vermelha ${ }^{14}$, sociedade que, entretanto, se propusera igualmente preparar pessoal feminino para a assistência aos feridos e doentes provocados pela guerra.

Os impedimentos governamentais estiveram na origem de comentários nos jornais, opinando alguns deles que tudo não passava de manigância política ${ }^{15}$. Perante o soçobrar de um projecto cujo núcleo estava na preparação de enfermeiras de guerra, muitos pensariam que a Assistência ia morrer pouco depois de ter nascido. Maria Amélia de Burnay abandonou a presidência, sendo substituída por Maria Josefa de Melo, condessa de Ficalho. Mas a sociedade não acabou, prosseguindo em moldes de alguma forma mais de acordo com a

${ }^{11}$ Diário de Notícias, 20/03/1916, p. 1, col. 7 e O Dia, 21/03/1916, p. 3, col. 3.

${ }^{12}$ A Opinião, 25/03/1916, p. 2, col. 2

${ }^{13}$ Em Março de 1916 um periódico católico, de Lisboa, abordava a necessidade de educação religiosa do soldado, fazendo-lhe chegar "as verdades santas do Evangelho". A Fé Christã, Março de 1916, p. 678.

${ }^{14}$ O Dia, 13/04/1916, p. 1, col. 5-6.

${ }^{15}$ Ibidem. 
tradição: auxílio às famílias dos soldados, confecção de agasalhos que enviavam para os lugares de combate, assistência às crianças... Mesmo reduzida nos objectivos conservou subcomissões regionais que haviam nascido logo após a sua constituição ${ }^{16}$ e acabou por se expandir ao Porto onde, já no início de 1917, surgiu uma associação com o mesmo nome e regendo-se pelos mesmos estatutos. A acção da Assistência das Portuguesas estendia-se às várias regiões do país, que foi dividido em duas zonas de influência. Os distritos do Norte recebiam o apoio da associação do Porto. A de Lisboa prestava ajuda nos distritos do Sul e do Centro, incluindo Viseu e Guarda ${ }^{17}$. As associadas que não desistiram da intenção de prestar serviço em hospitais de guerra tornaram-se "damas enfermeiras" da Cruz Vermelha. A própria condessa de Ficalho frequentou o curso e prestou provas de exame em Fevereiro de 1917 com mais dezanove consócias da associação a que presidia ${ }^{18}$.

A conjuntura da guerra era propícia a gestos que traduziam a sensibilização geral perante a possibilidade de ver partir um elevado número de jovens para uma situação de perigo. Assim, em Coimbra, paralelamente às diligências desenvolvidas por mulheres de Lisboa, nesses finais de Março e inícios de Abril de 1916 nascia a Sociedade da Cruz Branca de Coimbra, fruto do impulso dado pelo círculo social em que se movia o general Tamagnini de Abreu, chefe da divisão militar cuja sede se situava nesta cidade. A primeira presidente foi a sua própria mulher, Maria Isabel de Oliveira Pinto da França, mas as novas funções atribuídas ao general, nomeadamente as que o responsabilizavam pela organização do C. E. P., teriam contribuído para que a presidência da nova associação fosse conferida à condessa de Ameal. A agremiação tinha objectivos semelhantes aos da Assistência das Portuguesas às Vítimas da Guerra ${ }^{19}$. Mas, estando sob a protecção do comandante das forças que iam partir para o campo de batalha na Europa e, por outro lado, longe de Lisboa, que era o centro da luta entre o radicalismo livre-pensador e o catolicismo militante, os seus actos encontravam-se mais ao abrigo de remoques hostis.

Os critérios do Governo, que teriam estado na base da proibição ao funcionamento dos cursos de enfermagem da Assistência das Portuguesas às Vítimas da Guerra, não teriam tido muita justificação, se considerarmos que eles não foram respeitados quando se tratou de uma agremiação nascida posteriormente,

${ }^{16}$ Uma dessas subcomissões existia na Covilhã onde, em Julho de 1918, teve lugar um festival para recolha de donativos. O Liberal, 30/07/1918, p. 2, col.2.

${ }^{17}$ O Dia, 2/06/1917, p. 1, col. 5-6.

${ }^{18}$ Ibidem, 22/02/1917, p. 2, col. 3.

${ }^{19}$ O periódico Gazeta de Coimbra, a partir de 1 de Abril de 1916 vai acompanhando as actividades da Cruz Branca. 
muito ligada ao Estado: a Cruzada das Mulheres Portuguesas. Atendendo à conjuntura em que apareceu, poucos dias após terem surgido as primeiras notícias referentes à Assistência das Portuguesas às Vítimas da Guerra, não é descabido intuir que, no espírito dos seus promotores, tenha estado a intenção de travar o avanço de um movimento visto como reaccionário e hostil às instituições republicanas. Não conviria aos anticlericais deixar que uma sociedade "reaccionária" passasse a desempenhar um papel tão relevante na assistência aos soldados e suas famílias, susceptível de criar laços de gratidão e dependência.

A reunião de mulheres, presidida por Elzira Dantas Machado, esposa do Presidente da República, que deu origem ao nascer da Cruzada, teve um carácter oficial. Decorreu no palácio de Belém, com a presença de Bernardino Machado e de outros homens influentes da política republicana: general Pereira d'Eça, ex-ministro da Guerra e Comandante da $1^{\text {a }}$ divisão militar; general Rodrigues Ribeiro; capitão de fragata Leote do Rego, deputado e chefe da Divisão Naval, com um importante papel no movimento de 14 de Maio de 1915, que pôs fim ao governo de Pimenta de Castro; Luís Filipe da Mata, senador pelo Partido Democrático e Presidente do Conselho do Grande Oriente Lusitano Unido; Alfredo Rodrigues Gaspar, ministro das Colónias no Governo Presidido por Afonso Costa e que findara a 15 de Março; Dr. Levi Marques da Costa, Presidente da Câmara Municipal de Lisboa... Pretendia-se criar um movimento feminino que organizasse um programa de auxílio aos combatentes e suas famílias. Da reunião saiu o nome: Cruzada das Mulheres Portuguesas ${ }^{20}$. Ana de Castro Osório, uma das mais conhecidas feministas, ardente defensora da intervenção de Portugal na guerra e que viria a ser figura de proa do movimento, justificou assim a escolha da designação: "esse título abrange, duma maneira larga e patriótica, todas as formas de proceder e de sentir que tenham por fim honrar o nome que todas usamos com orgulho, de portuguesas, e auxiliar o país no sacrifício que a todas é pedido"21.

Dá a impressão que muitas das mulheres convocadas o foram, mais pelas ligações ao regime por parte dos maridos do que por elas próprias. Isso é especialmente visível nas que passaram a constituir a sua comissão central: Joana Gomes Galhardo, casada com Herculano Jorge Galhardo, senador e ex-ministro das Finanças (pertencera ao Partido Unionista, mas abandonara-o em 1915, transitando para o partido chefiado por Afonso Costa); Ester Norton

${ }^{20}$ Diário de Notícias, 28/03/1916, p. 1, col. 7.

${ }^{21}$ Ana de Castro Osório, Em Tempo de Guerra - Aos homens e ás mulheres do meu país, Lisboa, Editores: Ventura e Companhia, 1918, p. 16. 
de Matos, esposa do ministro da Guerra; Maria Luísa Braancamp Freire, esposa de Anselmo Braancamp Freire, Presidente da Câmara de Lisboa após o 5 de Outubro; Maria Leonor Correia Barreto, casada com António Xavier Correia Barreto, membro do Directório do Partido Republicano Português (mais conhecido por Partido Democrático) e presidente do Senado; Teresa Teixeira Queirós, esposa de Francisco Teixeira de Queirós, médico e romancista, com décadas de militância no Partido Republicano (fora deputado por Lisboa em 1885) e ministro dos Negócios Estrangeiros em 1915; Amália Leote do Rego, casada com o deputado do mesmo nome; Adelaide Menezes Fernandes Costa, esposa do ministro do Fomento; Raquel Freire de Oliveira Vicente Ferreira, provavelmente esposa de António Vicente Ferreira, ministro das Finanças entre 16 Junho 1912 e 9 Janeiro de 1913; Maria Amélia Oliva Aquiles Gonçalves, viúva do deputado Aquiles Gonçalves, que ocupou a pasta ministerial do Fomento durante o Governo presidido por Bernardino Machado, entre 9 de Fevereiro e 23 de Junho de 1914; Etelvina Pereira de Eça, esposa do comandante da $1^{\text {a }}$ divisão militar; Estefânia Macieira, casada com António Macieira, um dos mais conhecidos membros do Partido Democrático, senador, ex-ministro da Justiça, ex-ministro dos Negócios Estrangeiros; Maria Adelaide Coelho da Cunha, esposa do director do Diário de Notícias; Ana de Castro Osório (uma das poucas que não necessitava do nome do marido a ilustrar o seu). Estas mulheres estiveram presentes na residência presidencial. Mas foram ainda designadas para a Comissão Central outras que haviam estado ausentes "por motivos de força maior": "mesdames" (como informava o Diário de Notícias ${ }^{22}$ ) António José de Almeida (o chefe do Partido Evolucionista, que assumira a presidência de um Governo que se pretendia de União Sagrada); Afonso Costa (Ministro das Finanças); Pedro Martins, responsável pela pasta da Instrução; Augusto Soares, que tinha a pasta dos Negócios Estrangeiros; e D. Lucrécia Arriaga.

Por esta lista de mulheres que constituíam a Comissão Central da Cruzada das Mulheres Portuguesas pode afirmar-se que se trata do lado feminino da elite política que governava o país. O modo como é apresentada, com insistência nos cargos dos maridos (agravado pelo tratamento ao jeito francês), faz com que seja difícil, por vezes, descobrir os nomes das mulheres escondidas sob os véus matrimoniais.

Foram constituídas diversas comissões, de acordo com os vários sectores de auxílio. A comissão de assistência aos soldados era presidida por Ester Norton de Matos, Alzira Costa estava à frente da comissão hospitalar, Maria Isabel Mesquita de Carvalho (filha do poeta Guerra Junqueiro e esposa do Ministro

\footnotetext{
${ }^{22}$ Diário de Notícias, 28/03/1916, p. 1.
} 
da Justiça, pertencente ao Partido Evolucionista) presidia à comissão de enfermagem ${ }^{23}$. Existia uma comissão de propaganda - o que é revelador do peso dado a esta vertente - dirigida pela esposa de Fernandes Costa e secretariada por Ana de Castro Osório ${ }^{24}$.

Os promotores da nova associação - ou Ana de Castro Osório, que seria a grande propagandista da Cruzada - ambicionavam coordenar todas as iniciativas de assistência aos soldados e suas famílias. Desejavam que a Cruzada cobrisse todo o país, estendendo-se mesmo pelas comunidades residentes no estrangeiro, nomeadamente no Brasil, por meio de subcomissões ${ }^{25}$. As suas ligações políticas prometiam todas as facilidades tendo em vista o cumprimento de tal pretensão. O Governo dispunha dos instrumentos políticos capazes de promover o enquadramento de mulheres que, por ligações familiares ou pelas funções que desempenhavam, poderiam incentivar a anuência de outras. Os representantes do poder central (governadores civis e administradores concelhios) eram chamados a coadjuvar o movimento. Por intermédio da Câmara Municipal de Lisboa (o presidente assistiu à reunião) solicitar-se-ia a cooperação de todas as Câmaras existentes no país. Para tornar mais profícua a acção da Cruzada foi-lhe concedida, através de portaria assinada em 2 de Maio de 1916 pelo ministro do Trabalho António Maria da Silva, isenção de franquia postal, o que foi sentido como sendo de "extraordinário alcance para a propaganda"26, pois facilitava o envio frequente de cartas e circulares para todo o país e para as mais diversas entidades.

O pedido de cooperação às autoridades locais teve certamente grande peso no nascimento de muitas subcomissões. É a própria Ana de Castro Osório que se refere ao "apoio que lhes [administradores concelhios] pedimos constantemente, para a criação de pequenos núcleos da Cruzada"27. Algumas curtas notícias publicadas em jornais representam um bom indicativo acerca do acatamento às instruções recebidas de Lisboa. Assim, a Câmara Municipal de Manteigas aderiu ao movimento da Cruzada e prometeu auxiliar a subcomissão que se iria

${ }^{23}$ A insistência nos cargos dos maridos é evidente na notícia inserida num jornal: "As esposas dos srs. Ministros das finanças e da justiça, respectivamente presidentes das comissões de hospitalização e enfermagem conferenciaram com o sr. dr. Costa Santos sobre os trabalhos das suas comissões". A Capital, 14/04/1916, p. 1, col.5.

${ }^{24}$ Ibidem, 4/04/1916, p. 1, col. 9. O jornal apresenta as chefias das diversas comissões.

${ }^{25}$ Diário de Notícias, 28/03/1916, p. 1, col. 7.

${ }^{26}$ A Semeadora, 15/05/1916, p. 2, col. 1. Este periódico era o órgão da Associação de Propaganda Feminista, tendo Ana de Castro Osório como secretária de redacção.

${ }^{27}$ Ana de Castro Osório, Em Tempo de Guerra..., cit., p. 77. 
formar naquela vila ${ }^{28}$. Em Mortágua a Câmara Municipal encarregou Albertina Festas, sobrinha de António José de Almeida, de constituir a subcomissão da Cruzada. Como esta não se mostrou disponível, confiou esse encargo às professoras do concelho ${ }^{29}$ (que, certamente, não estariam em condições de recusar). Em Santiago do Cacém o administrador do concelho distribuiu por diversos estabelecimentos e casas comerciais um convite às senhoras da vila para uma reunião na Câmara Municipal. Segundo o texto da notícia, essa iniciativa foi tomada para "dar cumprimento à ordem emanada pelo Governo Civil" "30.

Os próprios jornais católicos não se furtaram a publicitar o nascimento de subcomissões da Cruzada. Em Maio de 1916 O Mensageiro, órgão dos católicos do distrito de Leiria, informou que, a convite do governador civil, tivera lugar, no edifício do Governo Civil, uma reunião de senhoras que haviam deliberado estabelecer uma comissão distrital da Cruzada das Mulheres Portuguesas. O redactor elogiou o convite e a adesão das senhoras, cujos nomes publicou ${ }^{31}$.

Como se podia ler no Diário de Notícias, pretendia-se "a mobilização espiritual das mulheres portuguesas" 32 . Através de um boletim de "Inscrição Patriótica" largamente distribuído, eram convidadas todas as mulheres a alistarem-se, escolhendo a maneira como podiam servir a Pátria:

"Cada mulher que preencher com toda a consciência o boletim junto, dizendo qual a maneira como pode servir a Pátria, cumpre um alto dever cívico"33.

Podia oferecer-se trabalho (enfermagem, confecção de roupa) ou dinheiro. Mas, mesmo "aquelas que nada mais derem que a sua fé, a sua boa vontade criando aos homens portugueses uma atmosfera de serenidade, de entusiasmo patriótico e de crença absoluta nos mais altos destinos da nossa Pátria"34, já estavam a ajudar na obra comum.

Era talvez um tanto utópico pretender levar a mensagem a todas as mulheres, mesmo àquelas (a grande maioria) que não tinham capacidade para ler o boletim ou responder ao questionário. A Comissão de Propaganda decidiu ainda

${ }^{28}$ Diário de Notícias, 22/05/1916, p. 1, col. 7.

${ }^{29}$ Ibidem, 8/06/1916, p. 2, col. 1.

${ }^{30}$ Ibidem, 27/04/1916, p. 1, col. 9.

${ }^{31}$ O Mensageiro, 17/05/1916, p. 2, col. 5. Informou igualmente que a Assistência aos Feridos de Guerra (designação dada por vezes à associação presidida pela condessa de Burnay) tinha muitas associadas em Leiria.

${ }^{32}$ Diário de Notícias, no 18140, 9/05/1916, p. 1.

${ }^{33}$ Ibidem, no 18111, 10/04/1916, p. 1, col. 6.

${ }^{34}$ Ibidem. 
enviar às Câmaras do país, incluindo ilhas e colónias, uma circular, sempre na pretensão de ligar a acção das mulheres portuguesas, "orientando-a para o alto fim patriótico"35. Todas as associações patrióticas e de beneficência e, mesmo, todas as escolas do país (primárias, secundárias e superiores) deveriam aderir à Cruzada através do pagamento de uma "quota de adesão", dando assim "alta prova de patriotismo" 36 .

Existia, assim, a ambição de integrar os grupos que se formavam pelo país, de auxílio aos militares, "para que um mesmo ideal espiritual de disciplina" presidisse ao movimento patriótico ${ }^{37}$. Seria uma espécie de União Nacional no feminino. Parece evidente que a direcção da Cruzada (e a sua retaguarda masculina) receava iniciativas de auxílio que não estivessem de acordo com a ortodoxia oficial.

Verdadeiramente a Cruzada das Mulheres Portuguesas não constituía a primeira tentativa de organizar as mulheres da mesma área ideológica, tendo em vista o auxílio aos combatentes. Logo no início do conflito, em 1914, um pequeno grupo de feministas, de que fazia parte Ana de Castro Osório, procurara dinamizar uma Comissão Feminina Pela Pátria, que angariaria donativos para auxiliar os soldados, não só os portugueses que estavam em África, mas também os belgas, franceses e ingleses ${ }^{38}$.

Essa diligência inicial parece ter tido muito pouco êxito. Porém, na nova conjuntura criada com a intervenção portuguesa na guerra, com o apoio do poder político, as condições eram muito diferentes. Ana de Castro Osório, a quem fora atribuído - ou ela escolheu com plena consciência - o aparentemente modesto lugar de secretária da Comissão de Propaganda, não desprezou as facilidades que se lhe ofereciam. Consciente do valor da propaganda, concedia entrevistas, escrevia nos jornais, fazia conferências. A militante feminista ambicionava mais do que criar um movimento de assistência aos militares e suas famílias. Queria aproveitar a oportunidade da guerra - que, em outros países, já conduzira a uma valorização do trabalho e das capacidades das mulheres - para criar, "pela propaganda, a conviç̧ão de que o trabalho inteligente das mulheres é indispensável à Pátria" 39 . Preparar as mulheres para o trabalho era uma tarefa prioritária. De tal modo que a comissão de que fazia parte alargaria o seu

${ }^{35}$ Ibidem, 2/05/1916, p. 1, col. 9.

${ }^{36}$ Ibidem.

${ }^{37}$ Ibidem, 17/05/1916, p. 1, col. 9

${ }^{38}$ Ana de Castro Osório, De Como Portugal Foi Chamado à Guerra-História para crianças, Lisboa, Casa Editora Para as Crianças, 1918, p. 78. Sobre esta comissão veja-se João Esteves, As Origens do Sufragismo Português, Lisboa, Editorial Bizâncio, 1998, pp. 121-122.

39 Ana de Castro Osório, Em Tempo de Guerra..., cit., p. 25. 
âmbito, tratando da "Propaganda e Organização do Trabalho"40. Em entrevista ao jornal A Opinião, a militante republicana forneceu informações sobre os fins da associação: mobilização moral do povo português e levantamento do espírito nacional, criando nos portugueses uma atmosfera de entusiasmo patriótico de "crença absoluta nos altos destinos da Pátria". Mas não se tratava somente de cuidar dos feridos ou adquirir roupas para os soldados; procurar-se-ia preparar as mulheres para substituírem os homens que partiam, organizar "uma cuidada e metódica propaganda do ensino agrícola feminino"41.

Neste anseio de unir as mulheres sob uma bandeira comum as dirigentes da Cruzada desejariam integrar na sua agremiação o esforço da Assistência das Portuguesas que, apesar de se apresentar desprotegida, era uma séria concorrente, capaz de desviar dos seus circuitos donativos consideráveis. Tendo-se mantido apagada, a associação presidida pela condessa de Ficalho irá surgir em força em Março de 1917, com a preparação da Festa da Flor (uma jornada que se pretendia de união, sem questões políticas) cujo produto reverteria para as vítimas da guerra. Desde que as primeiras notícias sobre o evento que se preparava começaram a circular, da parte das autoridades e de alguns jornais surgiram manifestações de desconfiança. No jornal O Mundo Ana de Castro Osório tentou desvalorizar a iniciativa. Não acreditava que as "senhoras monárquicas" se fossem misturar com o povo. Venderiam aos ricos, "aos seus pares", certas de que, assim protegidas, ninguém as ofenderia. Quanto ao destino a dar ao produto da venda, lembrava que já se encontravam constituídas diversas comissões de auxílio: as da Cruzada. Sugeria que as quantias recolhidas lhes fossem entregues. Assim sendo, "o povo receberá todo o auxílio mas não poderá receber a imposição de se confessar e comungar catolicamente para a ele ter jus"42. Nesta afirmação está explícita, em parte, a desconfiança relativamente ao uso que seria dado ao dinheiro obtido através da festa.

Apesar dos avisos e do clima de desconfiança que se gerou nos meios afectos ao Governo, a Festa da Flor teve um considerável sucesso. Era a primeira vez que, em Portugal, se realizava um acontecimento desse género. Conquanto em outras situações já tivesse havido vendas de flores, com mulheres pertencentes a classes privilegiadas oferecendo flores naturais em barracas decoradas ou bazares (normalmente como complemento de outras acções) com fins de carácter

${ }^{40}$ Designação que aparece em diversos relatórios da comissão e no livro citado de Ana de Castro Osório, Em Tempo de Guerra..., cit., p. 20.

${ }^{41}$ A Opinião, 2/05/1916, p. 1, col. 3-4.

${ }^{42}$ Ana de Castro Osório, "Venda de flores", O Mundo, 1/03/1917, p. 1, col. 3-4. 
humanitário, nos moldes em que decorreu em 15 de Março de 1917 nunca tinha acontecido. Centenas de mulheres, a maioria relacionada com a aristocracia monárquica, organizadas por grupos, percorreram as ruas de Lisboa. Os transeuntes eram abordados para que contribuíssem no auxílio aos combatentes, recebendo em troca uma modesta florinha artificial. Previamente muniram-se das necessárias licenças perante as autoridades republicanas, relutantes e desconfiadas e, sem preconceitos (naturais, tendo em conta as preferências monárquicas de muitas delas), solicitaram audiência ao Presidente da República, para que também ele pudesse contribuir. Foram ao Parlamento, às repartições públicas, aos bancos e estabelecimentos comerciais. Os incidentes desagradáveis foram muito reduzidos e, no final da jornada, mesmo os desconfiados viram-se forçados a reconhecer que a iniciativa constituíra um êxito ${ }^{43}$. Um êxito de tal ordem que, em breve, o núcleo portuense da Assistência das Portuguesas ${ }^{44}$ e a Cruz Branca de Coimbra $^{45}$ promoveram festas idênticas. Depois, outras cidades e vilas seguiram o exemplo das cidades mais importantes. Já não eram só as mulheres tidas como conservadoras que organizavam a festa da flor. Promoviam-se festas da flor a favor da Cruzada, da Cruz Vermelha ou, simplesmente, a favor dos combatentes locais. Mas a hostilidade anticlerical pela Festa da Flor manifestou-se em alguns lugares, quando a iniciativa partiu das mulheres católicas. Em Leiria, antes da jornada, apareceram espalhadas pela cidade folhas avulsas contendo avisos. O produto da festa não se destinaria aos feridos da guerra. Iria, sim, para a catequese, para auxiliar os padres que se encontravam no front e para outras obras de piedade católica ${ }^{46}$.

A nível nacional as "damas da flor" eram acusadas de desvio do dinheiro do povo para "bentinhos, catecismos e outras bugigangas" $"$. No Parlamento, Alexandre Braga, ministro da Justiça de então, acusou os católicos de estarem a aproveitar a guerra para, "a coberto duma hipócrita caridade", utilizarem o dinheiro obtido para comprarem "bugigangas e amuletos de pretos", que enviavam aos soldados ${ }^{48}$.

${ }^{43}$ A imprensa ocupou-se largamente da Festa da Flor nos dias 15/03/1917 e seguintes.

${ }^{44}$ A Liberdade, 17/04/1917, p. 1, col.1 e 18/04/1917, p. 2, col. 5.

${ }^{45}$ Gazeta de Coimbra, 26/05/1917, p. 1, col. 4 e 30/05/1917, p. 1, col. 5.

${ }^{46}$ O Mensageiro, 23/05/1917, p. 1, col. 1.

${ }^{47}$ Maria Lúcia de Brito Moura, ob. cit. p. 395. Haveria alguma razão para essas críticas. O católico J. Fernando de Souza (Nemo) afirma que as senhoras da festa da flor, do Porto contribuíram com valiosos donativos para a Comissão da Assistência Religiosa em Campanha. J. Fernando de Souza (Nemo), A Grande Guerra (Aspectos christãos e patrioticos), Lisboa, Typographia do Annuario Commercial, 1918, p. 294.

${ }^{48}$ Diário da Câmara dos Deputados, 8/08/1917. 
Quanto à Cruzada, a sua colagem ao aparelho do poder político permitiu-lhe uma expansão e uma influência que de outra forma não teria. Mas acarretar-lhe-ia muitas antipatias, apesar das constantes declarações de não haver intuitos políticos na sua acção. Isso mesmo foi asseverado por Elzira Dantas Machado, em entrevista concedida ao jornal $A$ Capital, tentando desfazer "tantas atoardas que por aí têm corrido"49.

A ambição de integrar (ou anular) todos os movimentos de auxílio aos combatentes atingiu mesmo a Cruz Vermelha, sociedade reconhecida oficialmente como auxiliar dos serviços militares de saúde. O decreto $\mathrm{n}^{\circ} 2493$ (Diário do Governo de 3 de Julho de 1916), emanado do Ministério da Guerra, assimilava explicitamente os elementos que integravam as comissões de hospitalização e de enfermagem da Cruzada ao pessoal referido no art. $9^{\circ}$ da Convenção de Genebra de 6 de Julho de 1906. As mulheres dessas comissões estavam autorizadas a transportar os feridos e doentes, assim como a organizar e administrar a formação necessária aos cuidados a prestar aos mesmos. O Estado atribuía-lhes os direitos da Cruz Vermelha, concedendo-lhes a possibilidade de usar os distintivos da Convenção de Genebra com as consequentes garantias internacionais ${ }^{50}$. Aliás, o próprio emblema da Cruzada - uma cruz vermelha semelhante à da organização internacional, com o nome da associação (Cruzada das Mulheres Portuguesas) envolvendo esse símbolo, era susceptível de originar confusões.

A nova sociedade recebeu os meios necessários a uma actuação autónoma. Para que a Cruzada tivesse hospitais próprios, foi cedido à sua Comissão de Hospitalização, a título precário, o edifício onde funcionara o colégio dos jesuítas, sito em Campolide, ocupado pelo Estado após a revolução de 5 de Outubro, "para nele fundar e manter um serviço autónomo de assistência médica e cirúrgica" 51 . A mesma comissão, que era presidida por Alzira Costa, foi autorizada a lançar uma "lotaria patriótica", cujo produto se destinava a um fundo de hospitalização de feridos e convalescentes de guerra ${ }^{52}$. As instalações do antigo convento de Arroios, retiradas aos Lazaristas após a queda da Monarquia, foram igualmente cedidas à Cruzada, mais precisamente à Comissão de Assistência aos Militares Mobilizados, da qual era presidente Ester Norton de Matos, esposa do ministro da Guerra. O edifício destinava-se a preparar um instituto para reabilitação de mutilados de guerra ${ }^{53}$.

${ }^{49}$ A Capital, 20/04/1917, p. 1, col. 1.

${ }^{50}$ A Manhã, 22/04/1917, 1, col. 3.

${ }^{51}$ Decreto no 2662, Diário do Governo, 3/10/1916.

${ }^{52}$ Decreto no 2486, Diário do Governo, 30/06/1916.

${ }^{53}$ A Semeadora, que regularmente publicitava as actividades da Cruzada, no seu número de Maio de 1917 noticiou o início das obras de adaptação do convento de Arroios. A Semeadora, 
A atribuição de tantas prerrogativas à Cruzada não podia deixar de provocar reparos nos sectores que combatiam o excessivo poder do Partido Democrático. O privilégio da lotaria conduziu a uma intervenção, na Câmara de Deputados, de Moura Pinto, deputado do Partido Unionista. Em sua opinião, a verba conseguida deveria ser doada à Cruz Vermelha. À Misericórdia de Lisboa competiria a preparação da lotaria e a arrecadação do dinheiro ${ }^{54}$. A intervenção não teve qualquer resultado e a lotaria foi por diante, embora, como se verá, tenha constituído um autêntico fracasso.

Toda esta protecção estatal concedida à Cruzada afectou a direcção da Cruz Vermelha que, por diversas formas, fez sentir o seu descontentamento. Em circular distribuída pela comissão central, em Abril de 1916, afirmava-se como a única auxiliar dos serviços militares de saúde, sendo uma sociedade neutral que, em conformidade com esse princípio, não era um "campo aberto" onde "qualquer parcialidade sectária, de qualquer ordem ou de qualquer procedência, julgue poder encontrar terreno apropriado ao desenvolvimento de propagandas particulares ou mesquinhas" ${ }^{55}$.

O texto do relatório da Comissão Administrativa apresentado em reunião da Assembleia Geral de 26 de Julho de 1917, apesar das naturais cautelas, é revelador do mal-estar sentido. Segundo se afirmava, a subscrição de guerra fora lançada "em circunstâncias difíceis", dada a "desorientação" e incompatibilidades entre pessoas que, apesar do "mais acrisolado patriotismo", não se haviam unido, concorrendo para o fim que todos tinham em vista: socorrer as vítimas da guerra. Em contraste com o que acontecia nos demais países beligerantes, a Cruz Vermelha em Portugal parecia isolada, "votada a um desprezo desconsolador e impedida de cumprir o seu dever patriótico". Mas, não obstante as dificuldades, o seu nome ter-se-ia imposto à generosidade e confiança dos concidadãos, encaminhando para a obra o "tristemente disputado óbolo de alguns milhares de portugueses" $" 56$.

Em comentário posterior, referente a textos enviados para o Diário de Notícias no sentido de informar o público sobre as actividades da Cruz Vermelha, o capitão Afonso de Dornelas, alto funcionário desta sociedade, confessava que tinha deixado transparecer "um pouco de azedume" perante os "mil processos" utilizados no sentido de "dispersar esforços e prejudicar a Cruz Vermelha" que

15/05/1917, p. 2, col. 1. Mas somente em Outubro foi publicado no Diário do Governo (portaria $\mathrm{n}^{\circ} 1113$ ) o regulamento do Instituto. Diário do Governo, 11/10/1917.

${ }^{54}$ Diário da Câmara dos Deputados, 27/04/1916.

${ }_{55}^{5}$ Diário de Notícias, 21/04/1916, p. 1, col. 9.

${ }^{56}$ Boletim Official da Sociedade Portugueza da Cruz Vermelha, Julho 1917, p. 201. 
não se prestara a "facciosismos políticos ou religiosos" 57 . Num desses textos, afirmava que a Cruz Vermelha socorria os feridos sem cuidar de nacionalidades, ideais políticos ou cultos religiosos, nada tendo de comum com associações que ultimamente se haviam fundado ${ }^{58}$. Para Dornelas, as convenções internacionais de protecção à Cruz Vermelha, assinadas pelo Governo de Portugal, estariam a ser esquecidas. As senhoras da sociedade, que dispunham de poder, umas pelas circunstâncias especiais de ligação com as primeiras entidades políticas, outras por estarem ligadas às primeiras entidades financeiras ou pelo prestígio dos seus nomes, deveriam estar a lutar pela bandeira da Cruz Vermelha, "a única, pelas convenções internacionais [...] que pode ser hasteada num hospital de sangue", tendo o respeito e o prestígio suficientes para dar protecção aos feridos ${ }^{59}$.

Podemos ler aqui acusações lançadas, quer à Cruzada das Mulheres Portuguesas, quer à Assistência das Portuguesas às Vítimas da Guerra. Contudo, a questão com esta associação parece ter sido resolvida facilmente, na medida em que algumas associadas vieram a prestar serviços na Cruz Vermelha. Como já foi dito, um grande número frequentou os cursos de enfermagem da Cruz Vermelha. Algumas desempenharam até tarefas capitais na organização dos seus hospitais - Junqueira e Ambleteuse (França) - e nos serviços de enfermagem aí decorrentes. O primeiro desses estabelecimentos foi instalado nos edifícios da vila de Santo António, à Junqueira, cedidos pela condessa de Burnay, uma das fundadoras e primeira presidente da Assistência das Portuguesas, que se tornou Dama da Cruz Vermelha e sua benemérita ${ }^{60}$.

Com a Cruzada os problemas foram bem mais graves. Embora não referindo explicitamente a instituição protegida pelo Governo, Afonso de Dornelas manifestou-se revoltado com a existência de sociedades que usavam símbolos da Cruz Vermelha para fins que, a seu ver, nada tinham de humanitário, buscando revestir-se de uma protecção a que não tinham direito ${ }^{61}$.

A referência à questão religiosa figura em vários escritos. Dornelas parece mesmo entender que aí se encontra a raiz do conflito. Num dos seus artigos afirma que, a não ser possível devolver a saúde aos doentes, se lhes deve garantir o conforto moral e espiritual de acordo com as diversas religiões. Para isso,

${ }^{57}$ Ibidem, Março 1918, p. 87.

${ }^{58}$ Diário de Notícias, 26/04/1916, p. 1, col. 8.

${ }^{59}$ Ibidem, 29/04/1916, p. 1, col. 8.

${ }^{60} \mathrm{O}$ Mundo, ao referir-se à inauguração do hospital da Junqueira, descrevia-o como sendo "um enorme edifício, magnificamente construído", "cheio de luz". O Mundo, 30/04/1917, p. 2 , col. 4.

${ }^{61}$ Diário de Notícias, 29/05/1916, p. 1, col. 4. 
a Cruz Vermelha contava com elementos competentes ${ }^{62}$. Aludindo à partida da formação sanitária da Cruz Vermelha, que ia estabelecer um hospital em Porto Amélia (Moçambique), informou que, nas instruções confiadas ao chefe da missão, Dr. Artur Machado, se recomendava que facilitasse aos doentes as visitas dos ministros das religiões por eles professadas ${ }^{63}$. Repare-se que, à data da publicação destes artigos, da parte do Governo não tinha sido ainda dado andamento às solicitações acerca da assistência religiosa aos militares em campanha.

No espaço reservado às notícias sobre a Cruz Vermelha O Diário de Notícias publicou a primeira parte de um artigo muito favorável, da autoria do Padre João Vacondeus. Este sacerdote referiu-se à missão da Sociedade, que dava o seu auxílio "sem distinções de classe, nacionalidade, religião, oposta às trevas dos enredos diplomáticos" ${ }^{\prime 4}$. Opinou que a desunião das mulheres, na grave conjuntura que se atravessava, só agravaria os males do país e que a política devia ser evitada em obras de caridade. O Diário de Notícias nunca publicou a segunda parte do texto (alegando falta de espaço), onde o autor recomendava: "É indispensável promover a entrada de capelães nesta Sociedade para se atender às necessidades dos crentes sacrificados ao dever patriótico"65.

A presença da Cruzada, com toda a confiança do Estado, que parecia desejar ter um organismo ao serviço dos seus interesses, substituindo a Cruz Vermelha, colocou esta em situação incómoda. Durante meses, as propostas de serviços, dirigidas ao Ministério da Guerra, versando o acompanhamento dos soldados em campanha ou em transporte - no caso dos feridos que fossem repatriados - ou, simplesmente, as questões sobre o que poderia fazer a Cruz Vermelha, ficavam sem resposta ${ }^{66}$. Em carta dirigida ao Ministro da Guerra, o almirante Domingos Tasso de Figueiredo, presidente da sociedade - retirar-se-ia pouco depois "por razões de saúde" ${ }^{\text {"67 }}$-, afirmava que, uma vez em guerra, a associação a que presidia esperara que em torno da sua bandeira se congregassem todos os esforços. Esperara igualmente que o auxílio do Governo se juntasse a toda

${ }^{62}$ Ibidem, 23/04/1916, p. 1, col. 7.

${ }^{63}$ Ibidem, 28/05/1916, p. 1, col. 9.

${ }^{64}$ Ibidem, 26/05/1916, p. 1 col. 6.

${ }^{65} \mathrm{O}$ texto foi publicado integralmente no periódico A Fé Christã, Junho 1916, pp. 74-77 e, mais tarde, no Boletim Official da Sociedade Portugueza da Cruz Vermelha, Agosto, 1918, p. 249.

${ }^{66}$ Arquivo da Cruz Vermelha, Acta da sessão extraordinária de 18 de Dezembro de 1916, Livro de Actas das Sessões da Comissão Central. Vejam-se os ofícios de 4 de Novembro e 7 (?) de Dezembro de 1916 dirigidos ao ministro da Guerra. Copiador da Correspondência Expedida, liv. $\mathrm{n}^{\mathrm{o}} 21$.

${ }^{67}$ Em carta de 22/05/16 o comité central de Lisboa dava a conhecer a eleição do general Joaquim Machado como substituto de Tasso de Figueiredo. Ibidem. 
essa cooperação. Não acontecera assim e toda a acção divergente traduzia-se praticamente numa oposição formal à Cruz Vermelha. Perguntava como levar ao conhecimento do Comité Internacional de Genève e dos Comités Centrais dos diversos países, "sem desprimor para Portugal", a notícia da "forçada abstenção" perante o estado de guerra ${ }^{68}$.

Quando, finalmente, o ministro deu o seu acordo à presença da Cruz Vermelha na frente europeia - o atraso em levar por diante os cursos de enfermagem da Cruzada pode ter ajudado na decisão ${ }^{69}$, bem como a percepção de que a Cruz Vermelha contava com fortes apoios internacionais -, surgiram problemas com as nomeações do pessoal que iria dirigir os serviços de montagem de um hospital em França. Através da análise da correspondência enviada aos departamentos governamentais, adivinham-se reservas colocadas pelo poder político a duas senhoras que partiram na missão preparatória. A que exercia funções principais, Maria Antónia Jervis Atouguia Ferreira Pinto Basto, pertencera, se não pertencia ainda, à Assistência das Portuguesas às Vítimas da Guerra; as suas irmãs desempenhavam importantes funções nesta organização. Segundo o representante da Cruz Vermelha, tratava-se de pessoas ilustradas, com prática de línguas estrangeiras - realçava-se o domínio da língua inglesa - tendo relações pessoais e amistosas com elementos influentes da Cruz Vermelha em França, Inglaterra e Estados Unidos da América, que teriam importância para o êxito da missão ${ }^{70}$.

Como explicar o retraimento de Norton de Matos perante a Cruz Vermelha? Seria somente por recear a acção de enfermeiras monárquicas ou católicas sobre os soldados feridos? Talvez não seja de excluir a hipótese de essas prevenções estarem relacionadas com os vínculos do ex-rei D. Manuel e da rainha D. Amélia, à Cruz Vermelha britânica, o que poderia facilitar eventuais visitas dessas duas individualidades aos soldados portugueses feridos ${ }^{71}$. Fosse qual fosse a razão,

${ }^{68}$ Arquivo da Cruz Vermelha, Copiador da Correspondência Expedida, Liv. no 20,28 de Abril de 1916.

${ }^{69}$ Escrevendo para O Mundo (24 de Maio 1917) Ana de Castro Osório informava que tinha aberto o primeiro curso de enfermeiras da Cruzada. O Mundo, 24/05/1917, p. 1. Ora, a esse tempo já a Cruz Vermelha tinha o seu corpo de enfermeiras.

${ }^{70}$ Arq. da C. V., Lisboa, Copiador da Correspondência expedida, Liv. n 22, 9/04/1917. $A$ Manhã, alguns dias antes transmitira a informação que a Cruz Vermelha Inglesa oferecera à sua congénere em Portugal o material sanitário e todo o apoio indispensável. A Manhã, 24/03/1917, p. 1, col. 4. Em reunião da comissão central da Cruz Vermelha Portuguesa, o presidente deu conta dos serviços prestados pela Cruz Vermelha da Grã-Bretanha. Boletim Official da Sociedade Portugueza da Cruz Vermelha, Agosto de 1917, p. 233.

${ }^{71}$ Ainda antes de Portugal estar envolvido na guerra, D. Manuel, como oficial da Cruz Vermelha, estivera em missão nas zonas de combates. D. Amélia prestou serviços como enfermeira, tendo sido 
acabou por decidir-se. Visitou o hospital da Junqueira, lugar de estágio das enfermeiras que iriam para França e parece ter ficado satisfeito ${ }^{72}$.

$O$ facto de ser a Cruz Vermelha a instalar um hospital perto da linha da frente constituiu, certamente, um desaire para a Cruzada. A ida de enfermeiras suas para junto dos combatentes estivera sempre entre as maiores aspirações das suas dirigentes e dos seus apoiantes. Em Abril de 1917 o jornal A Capital, defensor da instituição, referiu-se à sua "escola modelar" de enfermagem e ao envio próximo de senhoras portuguesas devidamente habilitadas para os campos de batalha da Europa ${ }^{73}$. Afinal, a Cruz Vermelha adiantara-se. O que não conduziu a uma completa desistência por parte da Cruzada. Esta sociedade iria conseguir um edifício em Hendaia (um antigo casino), que sofreu as necessárias obras de adaptação ${ }^{74}$. Mas estava muito distante da frente.

Num escrito para $O$ Mundo, Ana de Castro Osório não escondeu uma certa acidez, provavelmente fruto do despeito por ver a sua instituição suplantada e da desconfiança relativamente às mulheres da Cruz Vermelha que, em seu entender, não teriam os atributos patrióticos que seriam apanágio da Cruzada ${ }^{75}$. Benevolamente começava por afirmar-se certa de que todas as senhoras que iam prestar serviços em França "tinham pesado no íntimo das suas consciências", os "deveres e responsabilidades tremendas" que assumiam. De seguida garantia que os soldados “cumprirão nobre e heroicamente o seu dever". A desconfiança detecta-se na conclusão: "precisamos de ter a mesma certeza sobre as senhoras que forem, no voluntário cumprimento da sua difícil missão, para tratarem os feridos e doentes" $"$ "

condecorada pelo rei de Inglaterra com a Royal Red Cross ( $1^{\mathrm{a}}$ classe). Fernando Amaro Monteiro, Salazar e a Rainha - Advento da República. Restauração da Monarquia?, Lisboa, Prefácio, 2006, pp. 102-104.

72 A Capital, 9/10/1917, p. 1, col. 4.

${ }^{73}$ Ibidem, 22/04/1917, p. 2, col. 2.

${ }^{74}$ Pela portaria ${ }^{\circ} 1141$ foi aprovado o regulamento do Hospital Português de Hendaia, auxiliar $\mathrm{n}^{\circ} 1$ do Policlínico de Lisboa (Campolide), gerido técnica e administrativamente pela Comissão de Hospitalização da Cruzada das Mulheres Portuguesas. Diário do Governo, 13/11/1917.

${ }^{75} \mathrm{O}$ monárquico Diário Nacional apresentou na sua primeira página os retratos de três mulheres da Cruz Vermelha com a farda correspondente aos serviços que iam prestar. Segundo o articulista, tratava-se de senhoras da "mais fidalga estirpe" às quais se sentia preso por laços de parentesco e amizade. Diário Nacional, 16/11/1917, p. 1, col. 7

${ }^{76}$ O Mundo, 24/05/1917, p. 1.

O hospital da Cruz Vermelha, em Ambleteuse, iniciaria o seu funcionamento a 9 de Abril de 1918, com o terrível ataque alemão ao sector português. Mas, é evidente, o C.E.P. tinha os seus próprios serviços de saúde, cujo estudo não cabe no âmbito deste trabalho. No início, enquanto não se encontravam estabelecidos esses serviços, os feridos e doentes portugueses eram recebidos nos hospitais britânicos, onde trabalharam diversos médicos portugueses. Gradualmente foram 
O clima de suspeitas e as rivalidades entre as facções pesaram, certamente, no atraso da partida de enfermeiras para França. Existia outro problema: nunca antes houvera mulheres em instalações militares, dando ou recebendo ordens. Tornava-se necessário o suporte legislativo que tal permitisse. Os decretos $\mathrm{n}^{\mathrm{o}} 3306$ e $\mathrm{n}^{\mathrm{o}} 3307^{77}$ vieram preencher esse vazio legal. O primeiro autorizou a Comissão de Enfermagem da Cruzada das Mulheres Portuguesas a criar um curso destinado a preparar enfermeiras para "os hospitais militares do país e corpos expedicionários". Terminado o período de lições - cujo ensino, teórico e prático, seria fiscalizado por delegados do Ministério da Guerra -, para obter o diploma a candidata sujeitava-se a um exame perante um júri do qual fazia parte um médico nomeado pelo Ministro da Guerra. Teria de praticar com aproveitamento, durante pelo menos um mês após a conclusão do curso, num estabelecimento destinado à hospitalização militar. Os diplomas seriam passados pela Comissão de Enfermagem da Cruzada e visados pelo Ministério da Guerra. O outro decreto regulamentava o recrutamento de enfermeiras - que poderiam não ser da Cruzada - para os serviços de saúde do exército. As enfermeiras que não pertencessem à instituição teriam de praticar com aproveitamento durante um mês num hospital militar. Uma vez admitidas, tinham direito a transporte, alojamento e alimentação correspondentes a oficiais do exército e a vencimento, subvenções e reformas iguais aos alferes do quadro auxiliar dos serviços de saúde. Não poderiam prestar serviço em hospitais de campanha situados a menos de dez quilómetros da linha de batalha. Os vencimentos das enfermeiras-chefes, bem como as subvenções e reformas, seriam idênticos aos tenentes do quadro auxiliar de saúde.

Como se vê, na prática existiam duas instituições que se responsabilizavam pela preparação de enfermeiras de guerra: a Cruz Vermelha e a Cruzada das Mulheres Portuguesas. Para a parte prática a primeira servia-se do hospital da Junqueira e a segunda usava o hospital da Estrela ${ }^{78}$.

entrando em funcionamento ambulâncias e hospitais de sangue portugueses. Num destes o serviço de enfermagem estava a cargo de enfermeiras inglesas. Em outro hospital havia pessoal feminino contratado pelo governo português. Sobre este assunto veja-se Isabel Pestana Marques, Memórias do General 1915-1919. "Os Meus Três Comandos” de Fernando Tamagnini, Viseu, Fundação Mariana Seixas, 2004, pp. CXCVIII e ss.

Nestas condições entende-se que, em Agosto de 1918, uma enfermeira formada na "escola" da Cruzada prestasse serviço num dos hospitais do C.E.P., como noticiou o jornal $A$ Semeadora, 31/08/1918, p.2, col.2.

77 Diário do Governo, 21/08/1917.

${ }^{78}$ Conforme carta publicada em A Semeadora, 15/10/1917, p. 2, col. 1. 
Embora a Cruzada não tivesse conseguido substituir a Cruz Vermelha, mormente na abertura de um hospital na linha da frente, auferira um capital de prestígio e de poder considerável. No campo da assistência aos feridos ou incapacitados a Comissão de Hospitalização da Cruzada das Mulheres Portuguesas obteve os hospitais de Campolide ${ }^{79}$ (inaugurado em finais de 1917) e o de Hendaia, ainda em fase de organização no momento em que os democráticos foram forçados a deixar o poder. A Comissão de Assistência aos Militares Mobilizados alcançara a superintendência do Instituto de Reeducação dos Mutilados em Arroios.

Mesmo tendo em conta toda essa influência, parece muito exagerada, todavia, a afirmação contida num relatório, pretendendo que, sem a "acção inteligente" da Cruzada, o nosso país teria sofrido "a vergonha" de não ter mulheres com capacidade e energia para cumprir o seu dever durante a guerra ${ }^{80}$.

Se, no sector do tratamento de feridos, há uma duplicação de instituições que se arrogavam o direito a prestar serviços, nos outros campos da assistência aos combatentes essa duplicação é igualmente visível. A Cruzada das Mulheres Portuguesas e a Assistência das Portuguesas às Vítimas da Guerra perseguiam objectivos comuns. E os meios utilizados não seriam muito diferentes. Os soldados recebiam presentes: o tabaco e os agasalhos (senhoras de um e outro lado tricotavam cachecóis) seriam os mais vulgares, mas os jornais e os livros eram igualmente importantes; as famílias recebiam auxílio de formas diversas, desde enxovais para bebés a subsídios de rendas de casa. Embora tivesse sido decretado o pagamento de pensões às famílias dos combatentes, os atrasos nessas prestações ${ }^{81}$ e a subida de preços dos bens alimentares conduziam a situações dramáticas de pobreza. Segundo informações obtidas pelo jornal O Dia, após a Festa da Flor, em Março de 1917, foi uma "romaria" na sede da

${ }^{79}$ Por portaria de 21 de Julho de 1917 foi aprovado o regulamento do Instituto de Campolide, definido como "instituição de assistência particular". A administração era confiada a um conselho administrativo, composto por três delegadas da comissão de hospitalização, sendo uma presidente e outra secretária, e por outros elementos nomeados pela mesma comissão: enfermeira chefe, director clínico, subdirector clínico e director administrativo. República, 22/07/1917, p. 2, col. 2-3.

É de sublinhar o facto de não ser atribuída qualquer tarefa à comissão de enfermagem, nem sequer a escolha da enfermeira-chefe. Alguns dias depois a comissão de enfermagem anunciou que ia abandonar a associação. Uma carta de Angelina O'Connor Shyrley, secretária da comissão de enfermagem, dirigida nesse sentido a Joaquina Dantas Machado de Carvalho, assessora de sua mãe, Elzira Dantas Machado, foi publicada no República, 29/07/1917, p. 1, col. 5.

${ }^{80}$ Comissão de Assistência aos Militares Mobilizados e Afilhados de Guerra 1917-1918, Lisboa, Cruzada das Mulheres Portuguesas, p. 3.

${ }^{81}$ A Capital, 10/05/1917, p. 1, col. 6 e 12/09/1917, p. 1, col. 2. 
Assistência: mães, irmãs, esposas, filhas de mobilizados expunham misérias. Era preciso distribuir leite e remédios, pagar rendas de casa, acompanhar ao baptizado os recém-nascidos, resgatar roupas e máquinas de costura que haviam sido penhoradas. Em Abril de 1918 a associação mantinha um dispensário para os filhos dos mobilizados, com médico, ajuda alimentar e medicamentos ${ }^{82}$. Ambas as organizações - a Cruzada e a Assistência - pensaram em dar ajuda às mulheres dos combatentes que necessitassem de trabalhar fora do local de residência. A Cruzada dirigia uma casa em Xabregas, em instalações da Casa $\mathrm{Pia}^{83}$ - o seu carácter oficial ou semioficial dava-lhe direito a utilizar edifícios do Estado; a casa da Assistência situava-se no Pátio do Pimenta, 1- $\mathrm{A}^{84}$. Em Xabregas existia um espaço onde as mães podiam deixar os filhos enquanto trabalhavam. Do outro lado, uma comissão de senhoras, presidida por Sofia de Melo Breyner, instalou, num prédio da Rua do Jardim, à Estrela, a Casa Maternal, que funcionava como creche, abrigando filhos dos mobilizados pobres $^{85}$. As duas instituições preocuparam-se em legalizar situações de famílias irregulares, através do casamento ${ }^{86}$.

Mas a Cruzada ou, mais precisamente, a Comissão de Propaganda, especialmente interessada na luta pela autonomia das mulheres, para lá das específicas circunstâncias da guerra, dinamizou a criação de escolas profissionais que habilitassem as mulheres para o desempenho de uma profissão. A agricultura e as indústrias tradicionais domésticas, que ameaçavam cair no esquecimento, mereceram um desvelo especial. Ana de Castro Osório considerava esta tarefa a "mais útil e mais fecunda das obras da Cruzada" de 1917 abriu em Lisboa, no Campo de Santa Clara, a Escola Profissional n ${ }^{\circ}$, destinada a crianças do sexo feminino, filhas de soldados mobilizados ${ }^{88}$. Fora de Lisboa, eram apresentados como exemplares o "posto agrícola" de Alcobaça, as escolas profissionais de rendas, em Setúbal e em Viana do Castelo ${ }^{89}$.

${ }^{82}$ O Dia, 4/04/1918, p. 1, col. 5-6 e A Monarquia, 5/06/1918, p. 1, col. 6.

${ }^{83}$ A Manhã, 3/05/1917, p. 3.

${ }^{84}$ O Dia, 2/06/1917, p. 1, col. 5.

${ }^{85}$ Ibidem, 31/07/1917, p. 1, col. 5. Alegando falta de meios, alguns meses depois foi anunciada a intenção de entregar a obra a quem se dispusesse a mantê-la. A Cruzada assumiu esse encargo. República, 1/12/1917, p. 1, col. 2 .

${ }^{86}$ O Dia, 4/04/1918, p. 1, col. 5-6 e A Manhã, 12/01/1918, p. 3, col. 2.

${ }^{87}$ A Semeadora, 15/07/1916, p. 1, col. 3.

${ }^{88}$ A Opinião, 24/11/1917, p. 1, col. 3 e 26/11/1917, p. 1, col. 5. Em Março do ano seguinte teve lugar nessa escola uma exposição com distribuição de roupas aos filhos dos combatentes. Ibidem, 28/03/1918, p. 1, col. 4.

${ }^{89}$ A Semeadora, 15/07/1916, p. 1, col. 3. 
Todas estas obras exigiam dinheiro. Iniciativas variadas - peditórios, quermesses, bazares, representações teatrais, concertos - tinham lugar por todo o país. Os órgãos directivos das associações (incluindo a Cruz Vermelha) apelavam à generosidade dos portugueses, mesmo dos que viviam no estrangeiro. A colónia portuguesa no Brasil foi de uma admirável dedicação nesta conjuntura. A Cruz Vermelha Portuguesa recebeu mais do Brasil que do resto do mundo, incluindo Portuga ${ }^{90}$. Mas mais receberia certamente se não existisse a Cruzada das Mulheres Portuguesas. Esta associação, movendo-se na órbita do Governo e com uma secção de propaganda activa, atraía para si muitas dádivas. Os órgãos governamentais, quando lhes era dado escolher o destino dos bens doados, beneficiavam a Cruzada. Assim, em Maio de 1916, o Ministro da Guerra recebeu da Comissão Pró-Pátria, de Juiz de Fora (Brasil), um cheque no valor de cem libras, acompanhado de carta onde se pedia que fosse dado o destino conveniente, em benefício da Pátria. Norton de Matos entregou o presente à Cruzada $^{91}$. Casos destes repetir-se-ão. No Verão de 1917, o Ministro da Guerra, tendo recebido 4500\$00 de um grupo de portugueses residentes em Manaus, contemplou a Comissão de Hospitalização da Cruzada com 3000\$00, destinados às obras de Campolide ${ }^{92}$; pouco tempo depois, o ministro obteve do mesmo grupo de portugueses $4117 \$ 64$; entregou a quarta parte desse valor à comissão beneficiada anteriormente e deu à Comissão de Assistência aos Soldados Mobilizados (presidida por sua mulher) os restantes três quartos ${ }^{93}$; esta última recebeu ainda $32 \$ 22$, produto obtido de uma festa da flor que um professor organizara na sua freguesia e que enviara ao Ministro da Guerra ${ }^{94}$. Numa carta de Ester Norton de Matos, remetida ao sucessor do seu marido no Ministério, após a revolta militar de 5 de Dezembro de 1917, é afirmado que de diversas associações do Brasil chegava dinheiro "enviado directamente ao Ministro da Guerra, para este o distribuir pelas associações que têm essa missão". Referindo-se a uma importância recebida recentemente e de que lhe fora dada a maior parte (11212\$22), explicou que faltavam $875 \$ 00$, que haviam sido entregues à presidente da Escola Profissional $n^{\mathrm{o}} 1^{95}$ (que abrira recentemente em Lisboa, por iniciativa da Cruzada, como foi dito).

${ }^{90}$ Cruz Vermelha Portuguesa 1865-1925, Lisboa, Centro Tipográfico Colonial, 1926, p. 251.

${ }^{91}$ O Mundo, 10/05/1916, p. 1.

${ }_{92}$ A Manhã, 2/09/1917, p. 3, col. 2.

${ }_{93}$ A Manhã, 23/10/1917, p. 2, col. 7.

${ }^{94}$ Ibidem, 19/08/1917, p. 3, col. 4.

${ }^{95}$ Rodrigo Abreu, Vida Preciosa - D. Ester N. Norton de Matos, Viana do Castelo, Edição de Bernardo Dias Sucres., Lda., 1958, p. 89. 
A distribuição das quantias doadas por parte de Norton de Matos, a seu bel-prazer, demonstra falta de controlo, susceptível de conduzir a situações abusivas e ao despertar de suspeitas. $\mathrm{O}$ ministro poderia ter-se interessado pela Cruz Vermelha ou por outro organismo, mas parece não o ter feito. Já nem se coloca a possibilidade de conceder qualquer subsídio à Assistência das Mulheres Portuguesas. Quanto a esta associação, a iniciativa mais frutuosa foi, sem dúvida, a Festa da Flor ${ }^{96}$. Com certeza tinha os seus próprios benfeitores. Apenas um exemplo: o monárquico Diário Nacional informou que a esposa do ex-rei D. Manuel II, Augusta Vitória, oferecera cem libras à obra do "atelier" situado no Pátio do Pimenta ${ }^{97}$.

A assistência aos combatentes envolvia uma outra vertente que iria abrir um outro espaço de conflito entre as duas associações femininas. Referimo-nos ao movimento das Madrinhas de Guerra, que tanto êxito estava a conhecer nos países que entraram na guerra antes de Portugal. Também aqui o sector considerado mais conservador se adiantou. No mês de Março de 1917, isto é, pouco depois de ter partido para França o primeiro contingente (o que acontecera em finais de Janeiro), encontrava-se constituída a primeira comissão de mulheres que pretendia implementar essa instituição. Na sua grande maioria, pertenciam à aristocracia monárquica e católica. Sofia Burnay de Melo Breyner aparecia como presidente - conquanto Jane Bensaúde, uma francesa casada com Alfredo Bensaúde, director do Instituto Superior Técnico, tivesse tido grande influência, mormente na fase de arranque - mas, mais do que isso, era o rosto e a alma do movimento. Procurava-se auxiliar os combatentes, proporcionando a quem o desejasse uma correspondente que, de longe, enviasse uma palavra de conforto, um pequeno mimo que suavizasse a existência - um cachecol, um par de meias, tabaco - e se interessasse pelos familiares do militar. Porque entre os

${ }^{96}$ Em 1918 o produto da Festa da Flor, em Lisboa, não se destinou à associação presidida pela condessa de Ficalho. A conhecida poetisa Genoveva de Lima Ulrich, que no ano anterior fora a grande animadora, aproveitou a nova conjuntura política (aberta com a revolta de 5 de Dezembro), para retomar um projecto anterior: criar um hospital para apoiar os soldados que regressavam da guerra afectados psicologicamente. O produto da venda da flor destinava-se a concretizar essa ideia. A presidente da Assistência às Vítimas da Guerra organizou então a Festa do Cravo, que teve lugar no período das festas de Santo António. A Monarquia, 5/06/1918, p. 1 e 14/06/1918, p. 1, col. 4. O acontecido faz supor que haveria divergências no seio da associação. Aliás, logo após a queda dos democráticos a sua direcção recusou ser instrumentalizada pelo Diário Nacional. Este jornal monárquico pretendeu apresentar a Assistência das Portuguesas como vítima dos governos anteriores. Mas a condessa de Ficalho e outros elementos da direcção recusaram a "protecção" do Diário Nacional, negando-se a entrar no jogo de acusações. Diário Nacional, 22/12/1917, p.1, col. 5 e 23/12/1917, p.1, col. 5.

${ }^{97}$ Diário Nacional, 7/05/1918, p. 1, col. 7. 
deveres da madrinha de guerra estava o de entrar em contacto com a família do afilhado, informando-se das suas carências e procurando um lenitivo para as mesmas $^{98}$. Na prática o afilhado conseguia uma protectora que, por vezes, era pessoa influente. Em muitos casos, enquanto esperava pelo dia do embarque, o afilhado tornava-se visitante assíduo em casa da madrinha ${ }^{99}$.

Embora a instituição não se encontrasse vinculada a qualquer outra já existente, tinha afinidades com a Assistência das Portuguesas às Vítimas da Guerra e com os capelães militares que, em contacto com os afilhados, poderiam fornecer informações se algo de mau acontecesse. Os capelães podiam ser mesmo intermediários no pedido de madrinhas. Um deles, o padre José Ferreira de Lacerda, em carta a Sofia de Melo Breyner, enviou uma lista de nomes de soldados que pretendiam uma madrinha ${ }^{100}$. Como católicas, as madrinhas compreendiam a importância dos capelães e, por isso, Sofia de Melo Breyner auxiliou esses padres, essencialmente com papel de carta para os soldados, livros recreativos destinados às horas de repouso, instrumentos musicais... ${ }^{101}$ Ora, num tempo de anticlericalismo em que os mais radicais continuavam a ver na Igreja a principal adversária da construção de um "homem novo"102, liberto de superstições e capaz de levar a cabo a obra de regeneração da Pátria, as madrinhas de guerra tornaram-se rapidamente um alvo de ataques. Invectivadas pelo seu "sectarismo político e religioso" 103 , eram acusadas de se aproveitarem do estado da fragilidade psicológica dos soldados, que conviviam diariamente com a morte, para um trabalho de catequese religiosa através de medalhas, rosários e bentinhos. O Mundo apresentou como prova as divisas inscritas nas pulseiras oferecidas pelas madrinhas. Concordava com uma delas, oferecida por uma mulher - embora não republicana, tinha "uma alma gentilíssima de

${ }^{98}$ Ao informar os leitores sobre o aparecimento da instituição, o Diário Nacional deixava entrever que ela se destinava aos soldados com famílias carenciadas. Diário Nacional, 20/03/1917, p. 1 , col. 3 .

${ }^{99}$ Em carta ao Diário Nacional um mobilizado afirmou a sua gratidão para com a sua madrinha e marido desta, pela forma como o receberam no seu palacete, "cumulando-o de gentilezas e donativos". Diário Nacional, 25/04/1917, p. 2, col. 5. Não era caso isolado. A Capital (jornal que desvaloriza a obra de Sofia), refere-se à "romaria", no período antes do embarque, de rapazes da aldeia para casa da madrinha conseguida. A Capital, 25/05/1917, p. 1, col. 1.

${ }^{100}$ O Mensageiro, 8/08/1917, p. 1.

${ }^{101}$ Avelino de Figueiredo, A Cruz na Guerra (uma missão difícil). Roteiro e impressões, Lisboa, Ed. do autor, 1960, p. 375.

${ }^{102}$ Sobre este desejo de conseguir um "homem novo", veja-se Fernando Catroga, "O «Homem Novo»: Sob o Signo de Anteu e de Prometeu", O Republicanismo em Portugal. Da formação ao 5 de Outubro de 1910, Coimbra, Faculdade de Letras, 1991, pp. 449-464.

${ }^{103}$ O Mundo, $\mathrm{n}^{\mathrm{o}}$ 6073, 6/06/1917, p. 1. 
portuguesa" - que mandara inscrever a "nobre divisa": "Cumpre o teu dever e sê feliz". Mas revoltava-se com outras: "Deus te guie", "Que o Senhor dos Passos te acompanhe"; "Em ti, Virgem, confio. Padre Nosso, Avé Maria". Garantia a existência de madrinhas que impunham ao afilhado a obrigação de irem à missa, à confissão, à comunhão ${ }^{104}$.

No jornal $A$ Manhã, conquanto se considerasse o movimento interessante, pelos laços afectivos que se criavam entre madrinha e afilhado, admitia-se que o papel dessas mulheres seria prejudicial se acabrunhassem o espírito dos soldados em vez de levantarem o seu ânimo "com nobres inspirações patrióticas". Assim sendo, o Governo teria o direito e o dever de providenciar ${ }^{105}$.

O movimento das madrinhas de guerra ultrapassou o círculo de Sofia de Melo Breyner. A Sociedade da Cruz Branca de Coimbra, muito semelhante à Assistência das Portuguesas, abriu inscrições para candidatas a madrinhas de guerra ${ }^{106}$. Jornais de diferentes tendências colocavam as suas colunas à disposição dos mobilizados que desejassem, pela via do anúncio, conseguir madrinha. Contudo, pelo número de afilhados e pelos esforços desenvolvidos para satisfazer todos os candidatos, o nome de Sofia de Melo Breyner continuava a ser uma referência.

A Cruzada das Mulheres Portuguesas, rival das agremiações católicas, não ia ficar alheia a esta modalidade de apoio. Também não podia ser-lhe indiferente "a obra dissolvente e reaccionária" - expressões de O Mundo - das madrinhas. Aliás, este jornal apontava às "senhoras republicanas", como um dever, que contrariassem essa acção, "obtendo afilhados e incitando-os a serem bons cidadãos, isto é, a bem servirem a Pátria"107. Ana de Castro Osório, que alimentara a veleidade de que todas as organizações de auxílio ao soldado se integrassem na associação de que fazia parte, parecia não entender o entusiasmo pela nova instituição, atribuindo-o ao "nosso feitio sentimental e heróico"108. Afirmou mesmo o pioneirismo da Cruzada na medida em que, em seu entender, ela era verdadeiramente a "madrinha de guerra de todos os soldados e de todas as famílias que se lhe dirigem"109. Contudo, compreendeu que não podia ficar de fora, permitindo que as mulheres do sector adversário conquistassem os combatentes por aquele processo. Decidiu enveredar por essa via, através da obra "Afilhados de Guerra", considerando o "oportunismo da ocasião" e com

\footnotetext{
${ }^{104}$ Ibidem .

${ }^{105}$ A Manhã, 9/05/1917, p. 1, col. 3.

${ }^{106}$ Gazeta de Coimbra, 30/05/1917, p. 1.

${ }^{107}$ O Mundo, $\mathrm{n}^{\mathrm{o}} 6073,6 / 06 / 1917, \mathrm{p} .1$.

${ }^{108}$ Ana de Castro Osório, Em tempo de guerra..., cit., p. 82.

${ }^{109}$ Idem, ibidem, p. 83.
} 
"a ideia fixa de afirmar a obra moral da Cruzada", como declarou perante a assembleia geral da instituição ${ }^{110}$. Não se limitou, contudo, a seguir o modelo traçado. Não esperou que os mobilizados ou os que já se encontravam no campo de batalha se lhe dirigissem a solicitar madrinha. A partir da decisão tomada, mandou inscrever todos os combatentes e recomendou às subcomissões da Cruzada que inscrevessem como afilhados todos os soldados das suas áreas geográficas. As subcomissões eram, assim, madrinhas de todos os que partiam ${ }^{111}$. A Cruzada era a "grande madrinha colectiva" e o "Escritório dos Afilhados" a repartição por onde passava toda a correspondência. O carácter burocratizado da instituição intui-se facilmente no relatório apresentado em 1919, incidindo sobre as actividades do ano anterior. Apontavam-se despesas com viagens pagas a soldados que voltavam para as suas terras, "a pedido do Escritório". Aos que regressavam doentes, "encarregou-se o Escritório de os mandar visitar algumas vezes, distribuindo-lhes tabaco e outros mimos"112.

Garantia-se que, do "Escritório dos Afilhados", haviam saído 1550 cartas, milhares de jornais, livros - entre eles o de Ana de Castro Osório Em Tempo de Guerra. No mesmo relatório é referido que a Cruzada havia comprado quinhentos exemplares dessa obra, que foram distribuídos pelos afilhados ${ }^{113}$.

Nos finais de 1917 e no decorrer de 1918, A Semeadora, órgão da Associação de Propaganda Feminista, mas que, na prática, se tornou o órgão da Cruzada, publicou diversas cartas de soldados. Um deles, dirigindo-se à "minha boa e ilustre madrinha", afirma ter recebido um postal assinado por D. Albertina (o que demonstra que não era sempre a mesma mulher a escrever), agradece um livro e promete que o pedido para que lesse o livro aos "meus soldados" (trata-se certamente de um oficial) será satisfeito "para que se enraíze melhor nos seus corações o amor da Pátria" ${ }^{114}$. As cartas publicadas são idênticas, procurando deixar transparecer grande patriotismo. De um modo geral agradece-se um livro.

${ }^{110}$ Idem, "Afilhados de Guerra", Comissão de Assistência aos Militares Mobilizados e Afilhados de Guerra - 1917-1918, Lisboa, Cruzada das Mulheres Portuguesas, p. 17.

${ }^{111}$ Ibidem, p. 23.

112 “Afilhados de Guerra”, Relatório Geral - 9 de Março de 1918 - 6 de Junho de 1919, Lisboa, Cruzada das Mulheres Portuguesas, s. d., p. 58.

${ }^{113}$ Ibidem, p. 57. Relativamente ao livro, afirma-se: "Esta oferta foi das que melhor acolhimento tiveram, recebendo-se centenas de cartas cheias de gratidão".

A autora do livro recorria a todos os meios para vender as suas obras. Era uma forma de tentar resolver os constantes problemas financeiros. Chegou a escrever: "Nem eu trabalharia se não fosse para ganhar dinheiro". Dulce Maria Baptista Moacho, Ana de Castro Osório e as Origens do Feminismo em Portugal, tese de mestrado (texto policopiado), ISCTE, 2003, p. 65.

${ }^{114}$ A Semeadora, 30/12/1917, p. 3, col. 3. 
O periódico A Semeadora, enviado regularmente para a frente, era um instrumento de propaganda a favor da guerra. Mas funcionava igualmente como instrumento de propaganda da acção da Cruzada. Aliás, Ana de Castro Osório afirmou: "pela obra dos «Afilhados de Guerra» a ideia santa da «Cruzada» tem percorrido o mundo como uma esperança e como uma bênção" 115 .

Considerando a utilidade, junto dos soldados e da opinião pública, de um jornal que mais não fazia que "erguer o nome português" 116 , não espanta que também para essa obra da Cruzada o Governo fosse instado a dar auxílio. O Ministro da Instrução concordou em subsidiar o periódico. De 2000 exemplares (tiragem normal), passaria a 8000. Seriam distribuídos pelos "afilhados" e professores primários. Mas a verba não chegou a ser recebida, por ter eclodido o movimento de 5 de Dezembro de $1917^{117}$.

Ana de Castro Osório, ao criar a figura de "madrinha colectiva", tinha a consciência de que não teria um número suficiente de associadas para poder garantir uma madrinha para cada soldado. Admitia que algumas senhoras, sem estarem vinculadas à Cruzada, acedessem a ser madrinhas, "em nome da Pátria". Mas parecia não confiar muito na capacidade dessas mulheres que não aceitavam a tutela da Cruzada. Por isso, permitia-se explicar-lhes como deviam actuar: "devem fazer o possível por levantar o espírito das famílias dos soldados, explicando-lhes com clareza todos os factos destruindo os boatos e mentiras, que tanto estão prejudicando o país" ${ }^{118}$.

É provável que muitas cartas escritas pelas madrinhas católicas não correspondessem inteiramente aos desejos do sector mais activamente anticlerical. Contudo, quando esses militantes as acusavam de acabrunharem o ânimo dos soldados, falando-lhes na morte e incutindo-lhes medos de castigos na vida eterna, eram possivelmente guiados por preconceitos que não lhes deixavam entrever o outro lado. A opinião de um ex-combatente, o tenente Afonso do Paço, é diametralmente oposta, aludindo ao "mil vezes bendito papel das madrinhas de guerra" 119 . Atribui ao terço, oferecido por uma mulher quando foi para França, a coragem para vencer o medo. E escreve mesmo:

\footnotetext{
${ }^{115}$ Ana de Castro Osório, “Afilhados de Guerra”, Comissão de Assistência..., cit., p. 19.

${ }^{116}$ Assim afirmava Ana de Castro Osório em carta ao República, 24/12/1917, p. 1, col. 7.

${ }^{117}$ Ana de Castro Osório, ofendida com a recusa do novo ministro, fez publicar no República as cartas trocadas entre responsáveis da Cruzada e Ministério da Instrução. Ibidem.

118 “Afilhados de Guerra", Comissão de Assistência..., cit., pp. 23-24.

${ }^{119}$ Afonso do Paço, Cartas às Madrinhas de Guerra, Porto, Edição de Maranus, 1929, p. 59.
} 
"Se vós soubésseis, mulheres de Portugal, quantas Cruzes de Guerra colocastes no peito dos nossos soldados, dos vossos afilhados!" 120

Mesmo tendo em conta todas as divergências e hostilidades não se deve inferir que a Cruzada e as suas rivais - Assistência das Portuguesas /Madrinhas de Guerra - viviam em estado de guerra permanente. As fronteiras que as dividiam nem sempre estavam claramente definidas. Os núcleos centrais dos dois agrupamentos eram constituídos por mulheres pertencentes às classes superiores, pelo que os círculos de relações sociais se tocavam. Diligenciaram, por outro lado, não insistir nas questões políticas e religiosas, o que lhes permitiria a conquista de simpatias nos diferentes sectores da opinião pública. As mulheres da Cruzada não faziam campanha contra qualquer religião e, do outro lado, não havia, expressamente, qualquer intenção de apostolado religioso ou político. Entre os católicos, existiam discordâncias relativamente a divisionismos entre mulheres que, bem vistas as coisas, desejavam suavizar a situação dos que sofriam em consequência da guerra. Alguns jornais católicos publicitavam mesmo acções da Cruzada. Assim, não é de estranhar que franjas de cada um dos sectores invadisse o outro. Mesmo nos núcleos centrais era possível tal confusão. É o caso de Maria Adelaide Coelho da Cunha (esposa do director do Diário de Notícias) que, estando entre as fundadoras da Cruzada, integrou a comissão que, um ano depois, lançou o movimento das Madrinhas de Guerra ${ }^{121}$. Em determinados lugares mulheres católicas aceitaram integrar a Cruzada. Um caso exemplar é a subcomissão da Cruzada de Torres Novas. Um correspondente do jornal A Guarda - um dos mais conhecidos jornais ligados à Igreja, em diversas ocasiões suspenso a mando do Governo - em Junho e Julho de 1916 louvou a iniciativa da organização da Cruzada nessa vila. Da direcção desse "empreendimento tão simpático" que tinha "a caridade" como objectivo ${ }^{122}$, fazia parte Cândida de Azevedo Mendes Dinis da Fonseca, católica e com ligações familiares a dois homens muito conhecidos pela sua militância social e católica: o irmão, Carlos de Azevedo Mendes, enquanto estudante em Coimbra fora presidente do Centro Académico da Democracia Cristã e administrador da revista Estudos Sociais, órgão da associação; o marido, Álvaro Dinis da Fonseca, fora secretário de redacção da mesma revista ${ }^{123}$. Nos preparativos de

${ }^{120}$ Idem, ibidem.

${ }^{121} \mathrm{O}$ seu nome aparece na lista apresentada pelo Diário Nacional, 20/03/1917, p. 1, col. 3.

${ }^{122}$ A Guarda, 15/07/1917, p. 3, col. 1.

${ }^{123}$ Pinharanda Gomes, "Catolicismo Social e Democracia Cristã - Álvaro Dinis da Fonseca (1888-1918)”, (compilação, prefácio e notas de J. Pinharanda Gomes), Academia Internacional da Cultura Portuguesa, Boletim n ${ }^{\circ} 15,1988$, pp. 47-57. 
um festival para angariação de fundos as senhoras da subcomissão da Cruzada contaram com a participação de alguns homens, entre os quais Carlos de Azevedo Mendes ${ }^{124}$. O correspondente de $A$ Guarda parecia verdadeiramente entusiasmado com a obra da Cruzada, afirmando: "Santa Isabel, Rainha de Portugal, se ainda hoje fosse viva, seria decerto a mais incansável cooperadora da cruzada"125. Uma afirmação que, certamente, faria sorrir muitos políticos.

Conquanto se possa considerar o período de 1916-1917 o tempo glorioso da Cruzada, o certo é que, sob o brilho dos textos propagandísticos, alguma coisa não corria bem. $\mathrm{O}$ abandono da associação por parte dos elementos da Comissão de Enfermagem, descontente com o procedimento havido para com a ex-presidente e com a "forma arbitrária e ilegal" como funcionara "um simulacro" de assembleia geral em Xabregas ${ }^{126}$, revela um intenso mal-estar. Independentemente do funcionamento interno, a lotaria patriótica, fonte de tantas expectativas para a Comissão Hospitalar, constituiu um retumbante fracasso, pois não teve compradores em número suficiente. $\mathrm{O}$ facto pode dar uma ideia da verdadeira implantação popular do Governo. A 4 de Outubro de 1916, na véspera do dia marcado para a sua extracção, o decreto $\mathrm{n}^{\circ} 2664$ adiou o evento para 31 de Janeiro do ano seguinte, usando-se o argumento de que era necessário aguardar a resolução de negociações para serem deferidos os pedidos de bilhetes vindos do Brasi1 ${ }^{127}$. Depois, a saída da lotaria conheceu outros adiamentos e, a 18 de Setembro de 1917 o decreto $n^{\circ} 3374$ alterou as condições. Haveria cinco séries, com 120 contos de prémios cada uma e com sorteios em 31 de Janeiro (de 1918), 3 de Maio, 5 de Outubro, 31 de Janeiro de 1919 e 3 de Maio do mesmo ano. A falta de interesse do público não pode ser atribuída à crise económica, pois, como assegurava $O$ Dia, a Misericórdia continuava a colocar as suas lotarias sem qualquer dificuldade ${ }^{128}$.

A evolução política do país iria tornar impraticável a execução do programa governamental quanto à lotaria patriótica. Aliás, o movimento revolucionário de Dezembro de 1917, com a subida ao poder de Sidónio Pais e o crescer de influência da corrente que se opusera à concessão de privilégios à Cruzada, foi um verdadeiro terramoto para esta associação. O que não surpreende, tendo em conta toda a articulação entre o poder político e a corporação, cuja presidente era esposa do presidente da República deposto e as mulheres com

\footnotetext{
${ }^{124}$ A Guarda, 29/07/1917, p. 3, col. 2.

${ }^{125}$ Ibidem, 22/07/1917, p. 3, col. 1.

${ }^{126}$ República, 29/07/1917, p. 1, col. 5.

${ }^{127}$ Diário do Governo, 4/10/1916.

${ }^{128}$ O Dia, 17/12/1917, p. 1, col. 1-2.
} 
maiores responsabilidades eram parentes próximas de ex-membros do Governo. No decorrer dos acontecimentos que conduziram ao termo do governo de Afonso Costa, foi ocupado militarmente o Instituto de Campolide, o que revela a importância simbólica dessas instalações.

A comissão de hospitalização e, por arrastamento, toda a Cruzada, viu-se envolvida num caso desagradável envolvendo dinheiros públicos. Pouco depois do movimento militar que alterara a situação política, alguns jornais publicaram uma nota oficiosa dando conta que o Ministério das Finanças suspendera uma ordem de pagamento de 500 mil francos (cerca de 150 contos de réis da época) em cheques de 50000, passados a favor de Alzira Costa, presidente da comissão de hospitalização da Cruzada e esposa do ministro das Finanças e presidente do Governo derrubado, Afonso Costa. A quantia teria saído de uma verba destinada a cobrir despesas excepcionais resultantes da guerra. Tudo isto sem o "visto" da entidade competente.

Os adversários do ex-presidente do ministério não podiam deixar escapar um episódio destes, revelador de falta de transparência, que parecia misturar vida doméstica, política e dinheiros públicos ${ }^{129}$. Por outro lado, vinha tornar claro (pelo menos segundo a interpretação dos que não admiravam a Cruzada) que, afinal, a sociedade não era privada (como a Assistência das Portuguesas às Vítimas da Guerra) e a obra realizada não era fruto do seu próprio esforço, com donativos angariados por si. As verbas saíam do Tesouro público, tendo origem nos contribuintes ${ }^{130}$. Concordava-se que, se não existisse a Cruzada, o Estado teria de tomar iniciativas acerca da assistência aos doentes e mutilados, mas isso seria feito abertamente, sem deixar ao critério e boa-vontade de determinadas pessoas o uso de quantias avultadíssimas ${ }^{131}$. Alzira Costa, em carta a um sobrinho, que recebeu a incumbência de dar conhecimento do seu conteúdo aos jornais Diário de Notícias e O Século, acerca das verbas tão comentadas explicou que se destinavam ao serviço público e que se tratava somente de "empréstimos" do Estado a aplicar nas obras do hospital de Hendaia. Anteriormente, outros "empréstimos" haviam sido feitos para as obras do hospital de Campolide ${ }^{132}$. Num oficio da Comissão de Hospitalização, onde se pedia que o Ministério tomasse conta dos hospitais de Campolide e de Hendaia - petição um tanto escusada, pois era previsível que tal acontecesse-, explicava-se que, para satisfazer

${ }^{129}$ O Dia, $15 / 12 / 1917$, p. 1 , col. 3 .

${ }^{130}$ Idem, 15/12/1917 e 17/12/1917, p. 1 e Diário Nacional, p. 1, col. 5. Este jornal, monárquico, censurava à Cruzada o "alardear como actos de generosidade e produto dos seus próprios esforçoo" o que era feito à custa dos contribuintes.

${ }^{131}$ Diário Nacional, 17/12/1917, p. 1, col. 5.

${ }^{132}$ Ibidem, 17/12/1917, p. 1, col. 5. 
os empréstimos feitos, a Comissão contava com o produto da lotaria, com a generosidade dos benfeitores e com o alargamento dos benefícios do hospital de Campolide a particulares ${ }^{133}$.

Todo este assunto foi extremamente penoso para a Cruzada. A secretária geral, Palmira de Araújo Pádua, em carta ao director do jornal A Manhã, procurou demarcar os órgãos directivos da associação do que se passava com a comissão de hospitalização, explicando que cada uma das comissões sectoriais tinha autonomia, dispondo de fundos próprios. A comissão de hospitalização - e não a Cruzada - é que tivera autorização para dar andamento à lotaria, assim como recebera a concessão do edifício de Campolide ${ }^{134}$.

Este caso, de confusão entre a vida doméstica e as questões de interesse público, não é único. Como se viu, a propósito dos donativos enviados directamente a Norton de Matos, na sua qualidade de Ministro da Guerra, por associações patrióticas ou por particulares que os angariavam, o governante recebia e distribuía segundo o seu parecer. A esposa do ministro era a presidente da Comissão contemplada de um modo especial. Sua filha Rita era a secretária. A revolução de 5 de Dezembro apanhou Ester Norton de Matos com algum desse dinheiro em seu poder e, em carta dirigida ao novo ministro, pediu indicações sobre o que fazer a essa soma ${ }^{135}$.

O decreto $\mathrm{n}^{\mathrm{o}} 3732$, de 2 de Janeiro de 1918, pretendeu resolver as questões com a Cruzada. No seu preâmbulo, afirmava a "urgente necessidade de acautelar os interesses do Estado nas suas relações com a Cruzada das Mulheres Portuguesas e particularmente com as comissões da mesma Cruzada que levaram a efeito obras de hospitalização [...] em que se despenderam avultadas quantias, que saíram, na maior parte, dos cofres públicos"136. O Instituto Clínico de Campolide e o seu auxiliar, Hospital Português em Hendaia, assim como o Instituto de Reeducação dos Mutilados da Guerra, em Arroios, passavam para a posse do Ministério da Guerra. O Governo prometia nomear uma comissão para esclarecer a situação da Cruzada e suas comissões perante o Estado. O mesmo decreto anulou a legislação que tornara possível a lotaria patriótica e garantiu indemnização aos portadores dos bilhetes adquiridos ${ }^{137}$.

\footnotetext{
${ }^{133}$ A Manhã, 23/12/1917, p. 1, col. 6 .

${ }^{134}$ Ibidem, 22/12/1917, p. 1 col. 4.

${ }^{135}$ Rodrigo Abreu, ob. cit., p. 89.

${ }^{136}$ Diário do Governo, 8/01/1918.

${ }^{137}$ Ibidem.
} 
Nos meses seguintes, enquanto a situação não se esclarecia, o hospital de Campolide esteve subaproveitado e o Instituto de Arroios mantinha-se encerrado. Os mutilados que iam chegando do campo de guerra eram acolhidos no Instituto Pedagógico de Santa Isabel, em edifício da Casa Pia. Mas essas instalações eram muito insuficientes. Entre as enfermeiras da Cruzada, algumas haviam recebido preparação especificamente voltada para os mutilados e sentiam-se defraudadas nas suas expectativas, alimentadas, ou por uma generosidade romântica, ou pelo desejo de seguir uma carreira profissional aliciante. Provavelmente a maioria não estava interessada em questões políticas. Teimosamente, persistiam em continuar a prestar serviços aos mutilados ${ }^{138}$ e as vantagens dos seus serviços eram sentidas pelos médicos que consentiam na sua presença.

A direcção da Cruzada sentia-se injustiçada por lhe terem sido retirados os hospitais, sobretudo no caso de Arroios. Considerava que o estabelecimento pertencia à associação, que para ela conseguira importantes donativos. Garantia sempre que fora por sua iniciativa que se criara um estabelecimento destinado aos mutilados ${ }^{139}$. Aliás, em volta desse instituto a propaganda dos apoiantes da política de Afonso Costa e Norton de Matos tecia os maiores encómios, quer enaltecendo a solicitude do ministro, quer exaltando a generosidade da sua esposa ${ }^{140}$. Mas os adversários do Ministério caído em Dezembro de 1917 entendiam que o Estado (qualquer que fosse o governo) tinha o dever de cuidar dos mutilados de guerra e que a propaganda da Cruzada não tinha razão de ser, sobretudo sabendo que as despesas tinham sido feitas com dinheiros públicos. Há alguma razão nessas críticas. O lançamento da obra de reabilitação - e de obras da mesma natureza surgidas nos outros países em guerra - era ponderado por todos como necessidade cimeira. Em Maio de 1917 tivera lugar em Paris uma conferência de médicos de países aliados, cujo tema era precisamente a reeducação física e profissional dos inválidos, assim como as questões de natureza económica e social que lhe estavam subjacentes. Integravam a missão portuguesa os médicos António Aurélio da Costa Ferreira, Tovar de Lemos, José Pontes e Formigal Luzes ${ }^{141}$. O primeiro era director do Instituto de Santa Isabel, para onde eram encaminhados, para um primeiro exame, os mutilados. O nome do Dr. Tovar de Lemos está especialmente ligado ao hospital de Arroios, na medida em que foi a ele que a Comissão de Assistência

${ }^{138}$ A Capital, 1/04/1918, p. 1, col. 4 e 9/04/1918, p. 1, col. 5.

${ }^{139} \mathrm{~A}$ iniciativa da assistência aos mutilados era reivindicada antes do fim da guerra (a título de exemplo veja-se $A$ Semeadora, $\mathrm{n}^{\circ}$ 26, 15/08/1917, p. 1, col. 1.) e sê-lo-ia depois. Relatório Geral..., cit., p. 87.

${ }^{140}$ Rodrigo Abreu, ob. cit.

${ }^{141}$ A Capital, no 2413, 4/05/1917, p. 1, col. 2. 
aos Militares Mobilizados confiou a montagem e a organização. Fazendo o elogio do estabelecimento, que visitara, Maria Clara Correia Alves, uma das mulheres mais influentes do Conselho Nacional das Mulheres Portuguesas ${ }^{142}$, corroborou a opinião que se generalizara: "à Cruzada cabe a honra da fundação"143.

Somente em 24 de Maio de $1918^{144}$ foi publicado novo regulamento do Instituto Militar de Arroios que permitiu a admissão de enfermeiras especializadas. No hospital finalmente aberto, enfermeiras da Cruzada puderam aplicar os conhecimentos adquiridos. Mas a instituição pertencia ao Estado. Segundo o testemunho de Maria Clara Correia Alves, em Outubro o tratamento dos doentes estava inteiramente entregue a enfermeiras da Cruzada. No mês de Agosto haviam sido feitos 1866 tratamentos, somente com oito enfermeiras e um médico ${ }^{145}$. Assim sendo, apesar de o hospital de Arroios pertencer ao Estado, não parece despropositada ou fruto de simples propaganda a ligação que é costume fazer-se entre as enfermeiras da Cruzada e a reeducação dos mutilados da Primeira Guerra Mundial. Aliás, como o problema dos mutilados se prolongou para lá do fim da guerra, com as reviravoltas políticas a Cruzada viria a reaver o Instituto, que lhe foi restituído através da lei 959, de 7 de Março de $1920^{146}$, durante o governo presidido por António Maria Baptista.

Sem menosprezar as incontestáveis provas de empenho e simpatia de muitas associadas da Cruzada pelos mutilados - embora reconhecendo que as circunstâncias políticas favoreceram o seu envolvimento no minorar desse problema social - é de justiça não esquecer que a situação dos mutilados sensibilizava de modo particular a sociedade portuguesa. Nos últimos meses da guerra surgiram iniciativas diversas para conseguir donativos a seu favor. A implementação, no desporto da moda (futebol), da Taça Mutilados de Guerra ${ }^{147}$,

${ }^{142}$ Organização constituída em 1914, por iniciativa de Adelaide Cabete. Nela estiveram federadas mais de dez agremiações femininas portuguesas. João Esteves, "Conselho Nacional das Mulheres Portuguesas”, Dicionário no Feminino (séculos XIX-XX), Livros Horizonte, 2005, p. 243.

${ }^{143}$ Maria Clara Correia Alves, "Uma obra excelente”, Alma Feminina, Outubro 1918, p. 103 e ss.

${ }^{144}$ Diário do Governo, 11/06/1918.

${ }^{145}$ Maria Clara Correia Alves, art. cit.

${ }^{146}$ Boletim da Cruzada, $\mathrm{n}^{\circ}$ 1, Junho 1921. Certamente o chefe do Ministério, António Maria Baptista, apreciava o trabalho da Cruzada. Anteriormente, quando fora ministro da Guerra, (30-3-1919 a 29-6-1919), havia sido entregue à Cruzada a quantia de $18390 \$ 18$ que fora retida durante o período da «República Nova». Igualmente foi devolvida a importância de $11212 \$ 22$ que Ester Norton de Matos depositara na Caixa Geral de Depósitos, por ordem das novas autoridades. Relatório Geral..., cit., p. 23.

${ }^{147}$ A Capital, 10/07/1918, p. 1, col. 7 e 4/08/1918, p. 1, col. 3. 
comprova o sentimento geral. Senhoras da aristocracia visitavam os institutos de Santa Isabel e de Arroios. O jornal A Capital, que nas suas colunas abordava frequentemente o tema, salientou a acção da condessa de Valenças que mostrou especial carinho pelos mutilados. Recebeu-os na sua residência em Lisboa e na quinta que possuía em Sintra, fornecendo alimentação e transportes, que abrangiam os seus acompanhantes. Em passeios pela quinta, a dona da casa passeou, pelo seu braço, alguns visitantes ${ }^{148}$. Em certos sectores era considerada "a mais dedicada cooperadora da obra de reeducação dos mutilados"149. Mas o seu mundo não seria precisamente o das mulheres da Cruzada ou de grande parte dos seus apoiantes. O seu contributo para a Comissão de Assistência Religiosa em Campanha era de dez escudos mensais ${ }^{150}$, o que correspondia a um quinto do subsídio mensal de cada capelão ${ }^{151}$.

Pelo que tivemos ocasião de ver neste breve trabalho exploratório sobre a acção das mulheres na I Guerra Mundial, a assistência aos combatentes não foi um campo neutro onde fosse possível uma coexistência pacífica entre os grupos políticos em luta durante a I República. O conflito internacional era um episódio do combate que se travava no interior do país e o tratamento dos feridos tinha muito a ver com a verdadeira guerra pelo domínio das almas.

A situação dos soldados do C. E. P. sensibilizou os portugueses dos diversos quadrantes político-ideológicos. As mulheres, movendo-se no sector que tradicionalmente lhes era reservado, o da assistência, organizaram-se de modo a tentar apoiá-los e, assim, participar, de algum modo, no esforço que sentiam ser de todos. As associações femininas surgidas para o efeito não tinham como fim reivindicar direitos ou afirmar qualquer espécie de autonomia para as mulheres (embora, no caso da Cruzada, tivesse havido um aproveitar da oportunidade fornecida pela guerra). Num e noutro sector político, os homens estavam na retaguarda, em perfeita cumplicidade com as actividades desenvolvidas. Os interesses prioritários subjacentes ao auxílio aos soldados não eram precisamente idênticos nas duas associações: Assistência das Portuguesas às Vítimas da Guerra e Cruzada das Mulheres Portuguesas. Na primeira, as associadas tinham como referência os princípios da Igreja Católica, preocupando-se acima de tudo com a salvação das almas dos combatentes. Quanto às mulheres da

\footnotetext{
${ }^{148}$ Ibidem, 2/09/1918, p. 1, col. 6.

${ }^{149}$ Ibidem, 5/09/1918, p. 1, col. 6.

${ }^{150} \mathrm{O}$ Dia, $9 / 05 / 1917$, p. 2, col. 4.

${ }^{151}$ Os capelães recebiam um subsídio mensal de $50 \$ 00$ que depois passou a ser fixado em francos, devido às flutuações cambiais. Diário Nacional, 23/03/1917, p. 1, col. 7.
} 
Cruzada, que, de algum modo, combatiam os princípios que animavam as primeiras - o que não quer dizer que todas tivessem consciência disso - pareciam especialmente interessadas com o ânimo patriótico a dar aos soldados para que eles pudessem desempenhar a tarefa de que haviam sido incumbidos, com honra para a Pátria e para o Governo da República. As lutas políticas e religiosas, que dividiam os homens num tempo excepcionalmente conturbado, repercutiam-se inevitavelmente no sector feminino.

É evidente que, de um e outro lado, existiam autênticos sentimentos de generosidade e solidariedade para com os carenciados: soldados, sobretudo na situação de feridos ou de mutilados, e seus familiares. Qualquer que fosse o campo em que se situavam, movidas pelo patriotismo ou pela caridade cristã, algumas dessas mulheres conseguiram uma visibilidade difícil de obter em tempo normal. Revelaram dotes de inteligência, criatividade e organização. Mas os ódios políticos perturbaram a sua acção, embora pareça que, entre elas, as lutas seriam bastante mais diluídas, tornando possível, em alguns casos, obter consensos. Mesmo os homens, impiedosos nas lutas normais, moderavam o tom quando se tratava de mulheres pertencentes ao campo adversário. 